\title{
A TEORIA DA SOCIEDADE DE RISCO COMO INSTRUMENTO PARA A COMPREENSÃO DA EMERGENCIA DOS MOVIMENTOS SOCIAIS URBANOS NO BRASIL: UM CONTRAPONTO CRÍTICO
}

\author{
Clóvis Eduardo Malinverni da Silveira ${ }^{1}$
}

\begin{abstract}
Resumo
O presente texto ocupa-se da teoria da sociedade mundial do risco, tal como desenvolvida por Ülrich Beck, como instrumento para compreensão das Jornadas de Junho no Brasil, bem como de outros movimentos sociais de protesto (tais como os eventos associados ao Ocuppy e ao Indignados). Emergindo no meio urbano na última década, esses eventos associaram o problema das condições de vida nas cidades a uma crítica radical da ordem político-econômica mundial. O objetivo não é oferecer interpretações acabadas acerca dos movimentos sociais, e sim refletir criticamente sobre importantes conceitos presentes na obra Beck, discutindo em que medida poderiam contribuir para a elucidação do significado e do alcance político-jurídico dos referidos eventos. Redigido em forma de ensaio, o texto pergunta, sob vários ângulos, pelas vantagens e limites da sociologia do risco de Beck, com destaque para o contraponto com as teorias críticas contemporâneas comprometidas com o propósito de pensar a subjetividade política como evento, como em Jacques Rancière e Slavoj Žižek.
\end{abstract}

Palavras-Chaves: risco, democracia, movimentos sociais, novos direitos.

\section{INTRODUÇÃO}

As séries de manifestações populares ocorridas em várias partes do mundo nos últimos anos possuem traços comuns bastante significativos. Assim como os atos ligados aos movimentos Ocuppy e Indignados, as Jornadas de Junho brasileiras consistiram em movimentos urbanos, que emergiram sobretudo em grandes centros. Ademais, surgiram como forma de resposta ao problema da vida nas grandes cidades, trazendo à tona temas como a precarização dos transportes e dos serviços públicos em geral, a segregação espacial (favelização, guetificação e gentrificação inclusos), o crescimento da desigualdade, o advento de medidas de austeridade na Europa, o desemprego, a dificuldade de acesso à habitação e a negação de diversos direitos sociais básicos. Esses traços

\footnotetext{
${ }^{1}$ Doutor em Direito pela Universidade Federal de Santa Catarina (UFSC). Professor Doutor Adjunto I na Universidade de Caxias do Sul (UCS), atuando nos cursos de e graduação e mestrado acadêmico em Direito. E-mail: clovisems@gmail.com

${ }^{2}$ Conforme informações do The Guardian, os protestos associados ao movimento Occupy e ao movimento Indignados haviam ocorido, até a data de 18 de outubro de 2011, em 951 cidades de 82 países. Cf. ROGERS, Simon. Occupy protests around the world: full list visualised. The Guardian.London, p. 1-2. 14 nov. 2011. Disponível em: <http://www.theguardian.com/news/datablog/interactive/2011/oct/18/occupy-protests-map-world>. Acesso em: 08 mar. 2015 . 
aproximam eventos resultantes de contextos muito diversos, o que tem permitido a proposição de eixos abrangentes de análise. Para as pretensões deste escrito, portanto, os argumentos desenvolvidos podem ser considerados aplicáveis ao conjunto das referidas manifestações, resguardadas suas especificidades.

$\mathrm{Na}$ esteira das ondas internacionais, também os manifestantes brasileiros foram organizados em "coletivos não hierárquicos, com gestão descentralizada", construídos por meio de formas tipicamente contemporâneas de comunicação - tais com as redes sociais virtuais e os telefones celulares - e foram marcados pela presença de variadas faixas etárias (na sua maioria jovens) e classes sociais (embora com predomínio de classes médias). É fundamental destacar que, muito embora um certo número de pautas específicas esteja na origem das manifestações brasileiras, as Jornadas de Junho não ficaram adstritas a assuntos pontuais. Observou-se um sentido mais ousado de insatisfação popular, bem como um tom de questionamento profundo da ordem social estabelecida (mais bem articulado ou mais difuso, conforme as circunstâncias).

Apesar dos atos de insatisfação contra o governo federal, ou contra governos estaduais e municipais particularmente considerados, os protestos de 2013 não miraram apenas os governos estabelecidos ${ }^{4}$, senão também o sistema político-partidário e a própria conformação das estruturas de poder político e econômico. $\mathrm{O}$ fato de não ter sido constituído qualquer projeto político alternativo suficientemente claro, capaz de responder às insatisfações de maneira ampla, não desmente o teor de radicalidade ${ }^{5}$ dos eventos. $\mathrm{O}$ argumento do teor radical dos protestos também não pode ser refutado tão somente em razão da emergência de protestos mais recentes de cunho político-eleitoral, antes ou após o pleito de 2014. Mesmo as ações do Movimento Passe Livre (MPL) ${ }^{6}$, desde o início das Jornadas de Junho, não foram apenas protestos contra o custo e a precariedade do transporte urbano: integraram um coro de indignação contra as distorções da representação política, e de denúncia dos efeitos deletérios da economia globalizada. Esse conteúdo mais universalista implícito na voz dos manifestantes aparece, por exemplo, em alguns slogans amplamente divulgados, tais como "não é só pelos 20 centavos", "queremos um Brasil melhor" ou "desculpe o transtorno, estamos mudando o país".

É certo que a abordagem dos atos de protesto pela mídia, pelos movimentos sociais, pelos políticos e pelos intelectuais não é unívoca: a pluralidade de vozes traduz a efervescência de múltiplos posicionamentos

\footnotetext{
${ }^{3}$ GOHN, Maria da Glória. Manifestações de junho de 2013 no Brasil e praças de indignados no mundo. Petrópolis: Vozes, 2014, 157 p.,p. 9.

${ }^{4}$ Rubens Figueiredo afirma que a manifestação foi "extraordinária e multifacetada", e que os eventos tiveram caráter multicausal. Ao listar os "fatores de irritação" que, associados, culminaram na surpreendente explosão cívica, cita a "escalada da esperteza governamental", a "empáfia debochada", a "corrupção destrambelhada", a "incompetência de alto impacto" - causas mais diretamente voltadas à crítica do governo estabelecido. FIGUEIREDO, Rubens. A "espiral do silêncio e a escalada da insatisfação". In: FIGUEIREDO, Rubens (org.) A sociedade enfrenta o Estado. São Paulo: Summus, 2014.

${ }^{5}$ Utiliza-se "radicalidade" no sentido de pretender-se colocar em pauta os problemas em sua raiz, para além da negociação em torno de demandas pontuais.
}

${ }^{6}$ MOVIMENTO PASSE LIVRE. Não começou em Salvador, não vai terminar em São Paulo. Maricato, Ermínia [et. al.] Cidades Rebeldes: passe livre e as manifestações que tomaram as ruas do Brasil. São Paulo: Boitempo, 2013. 112 p. p. 13-18 vol.08, n. 03, Rio de Janeiro, 2015.pp. 1913-1948 
políticos e ideológicos, os quais procuram fazer prevalecer suas próprias razões e interpretações. Para além dos intérpretes, os próprios manifestantes não constituíram, de fato, um "bloco homogêneo" justamente por este motivo que se faz necessário o questionamento acerca do significado político mais profundo destes eventos, particularmente em termos de política emancipatória: se podem ou poderiam vir a traduzir transformações sociais estruturais; ou, se constituem reflexos de tensões graves, que desafiam de maneira inelutável um determinado estado de coisas e abrem o espaço, ao menos potencialmente, para um cenário substancialmente novo em termos de efetivação de direitos sociais. Observe-se que milhares de manifestações emergiram globalmente, de maneira quase simultânea. Ressalvadas as diferentes conjunturas nacionais e locais, a heterogeneidade dos manifestantes, a multiplicidade das pautas e a diversidade dos conteúdos ideológicos envolvidos, é certo que todos as referidas séries de manifestações canalizaram sentimentos contraditórios de indignação como há muito não se via, bem como anseios por mudanças profundas no cenário político/econômico/social, ainda que não fique claro em que direção.

No presente texto, não se pretende oferecer respostas a estas indagações, que foram e são objeto de diversas pesquisas. O objetivo, menos ambicioso, é discutir de até que ponto a noção de sociedade de risco, tal como cunhada por Ülrich Beck, contribui para a elucidação do significado e do alcance político-jurídico destes eventos de características inauditas; e, no mesmo sentido, qual a pertinência de conceitos fundamentais, tais como a ideia de modernidade reflexiva, irresponsabilidade organizada, cosmopolitismo metodológico, sociedade mundial do risco, renovação do político. A questão é relevante, tendo em conta a grande influência do autor alemão, bem como dos argumentos centrais de sua obra, no meio acadêmico brasileiro e internacional, desde a década de 1980 até os dias atuais. Ademais, o propósito que parece nuclear, na obra de Beck, é o de situar a noção de risco no centro de uma teoria compreensiva da sociedade atual ${ }^{8}$. É justamente em razão desta pretendida abrangência que a teoria deve ser colocada à prova, tanto quanto possível, em face dos mais áridos problemas contemporâneos. Pretende-se, em suma, refletir criticamente sobre as potencialidades da abordagem do mundo social como sociedade (mundial) de risco no sentido de clarificar em que aspectos ela poderia melhor contribuir e, principalmente, em que aspectos não conteria as ferramentas teóricas mais adequadas.

Conforme já era evidente em Risk Society: Towards a New Modernity e em Ecological politics in an age of Risk ${ }^{10}$, entende Goldblatt ${ }^{11}$, a obra de Beck é econômica em definições cuidadosas ou descrições analíticas e sistemáticas. Como reconhece o próprio Beck em sua obra pioneira, cujo objetivo anunciado era o de tornar

\footnotetext{
${ }^{7}$ GOHN, Maria da Glória. Manifestações de junho de 2013 no Brasil e praças de indignados no mundo. Petrópolis: Vozes, 2014, p. 142-143.

${ }^{8}$ GOLDBLATT, David. Teoria Social e Ambiente. Tradução Ana Maria André. Lisboa: Instituto Piaget, 1998, p. 228.

${ }^{9}$ BECK, Ülrich. Sociedade de risco: rumo a uma outra modernidade. Tradução Sebastião Nascimento. São Paulo: Edições 34, $2010,367 \mathrm{p}$.

${ }^{10}$ BECK, Ülrich. Ecological politics in an age of risk. Translated by Amos Weisz. London: Polity Press, 1995. 215 p.

${ }^{11}$ Id., p. 227-228.
} 
mais visível o futuro que ali já se anunciava, seus argumentos não seriam representativos como exigem as regras da pesquisa social empírica, e não contêm as salvaguardas metodológicas apropriadas ${ }^{12}$. Beck irá demonstrar maior preocupação com os estudos empíricos nas suas últimas obras. Entretanto, vale observar que esse estilo mais ensaístico, no geral pouco rigoroso sob o ponto de vista metodológico das ciências sociais empíricas, é capaz, por sua leveza, de produzir brilhantes insights, assim como de recair em fragrantes equívocos, além de resultar uma boa porção de controvérsias.

Assim, não parece inapropriado abordar o pensamento da sociedade de risco de maneira igualmente ensaística, buscando explorar criticamente aqueles que se supõem os limites deste corpo conceitual no que diz respeito ao enfrentamento da temática dos movimentos sociais urbanos e de seu potencial emancipatório. Ressalte-se que, uma vez que o próprio Beck sempre procurou desempenhar um papel de teórico crítico, principalmente do chamado pós-modernismo, da industrialização e do mundo neoliberal, o ato de submeter suas teses à crítica a partir de outras lentes teóricas, testando sua abrangência, também consiste em uma maneira de dignificá-las. As reflexões aqui empreendidas não estão estritamente contidas em um marco teórico específico, mas são influenciadas pelas chamadas novas teorias críticas $^{13}$, particularmente por aquelas teorias contemporâneas comprometidas com o propósito de pensar a subjetividade política como evento, com é o caso de Jacques Rancière, Alain Badiou e Slavoj Žižek. A forma como se compreende o evento político nestas teorias permite um frutífero contraponto com a teoria da sociedade de risco, na qual o problema do político é mediado, sobretudo, pelas noções de risco e reflexividade.

\section{O RISCO COMO OBJETO DE ESTUDO E O LUGAR DA TEORIA DA SOCIEDADE DE RISCO FACE AS CIÊNCIAS SOCIAIS}

A análise da enigmática noção de risco nas ciências sociais revela um ganho progressivo em termos de evidência acadêmica: partindo de um uso estritamente técnico e pretensamente objetivo; passando por um uso

\footnotetext{
12 "Algumas passagens poderão [...] acabar soando estridentes, precipitadas ou excessivamente irônicas [...]. Os argumentos aqui apresentados não são necessariamente representativos, como exigiriam as regras da pesquisa social empírica. Eles se pautam por uma outra pretensão: a despeito de um passado ainda vigente, tornar visível o futuro que já se anuncia no presente [...]. Nesse sentido, este livro contém um pouco de teoria social prospectiva, empiricamente orientada - mas sem todas as salvaguardas metodológicas". BECK, Ulrich. Sociedade de risco: rumo a uma outra modernidade. Tradução Sebastião Nascimento. São Paulo: Edições 34, 2010, p. 11-12.

${ }^{13}$ Ramzig Keucheyan utiliza a expressão new critical theory por referência à renovação da crítica política e social iniciada na segunda metade dos anos 1990, a partir das greves francesas de novembro/dezembro de 1995, dos protestos contra a OMC em Seattle em 1999 e do primeiro Fórum Social Mundial de Porto Alegre, em 2001. Estas novas teorias críticas rejeitam o axioma da neutralidade valorativa postulado por Weber e compartilham o pressuposto de que se vive um período histórico de transição, muito embora seja prematuro oferecer respostas definitivas sobre o significado disso. Ademais, são teorias cujo criticismo não concerne a aspectos particulares da ordem social existente, desafiando-na de maneira tendencialmente abrangente. KEUCHEYAN, Ramzig. The Left Hemisohere: mapping critical theory today. Translated by Gregory Elliott. London: Verso, 2013,264 p.
} vol.08, nº. 03, Rio de Janeiro, 2015.pp. 1913-1948 
alargado, em razão do aporte das ciências sociais (tais como a antropologia e a sociologia); e culminando no conceito de sociedade de risco, onde o risco torna-se a lente pela qual se pretende compreender e teorizar todo o campo do social. Tendo isso em conta, debater a posição que a obra de Beck ocupa na história das ideias sobre o risco pode ser de grande utilidade a fim de compreender algumas das vantagens e limitações que a teoria da sociedade de risco oferece na leitura da emergência dos movimentos sociais urbanos.

$\mathrm{O}$ cotejo ${ }^{14}$ entre as tipologias propostas, dentre outros autores, por Guivant ${ }^{15}$, Marandola Jr. e Hogan ${ }^{16}$, e Acosta ${ }^{17}$ permite falar em três ou quatro grandes abordagens acerca do risco, a depender da posição ocupada pela teoria da sociedade de risco nesta árvore genealógica - se um percurso autônomo, ou se um desdobramento de outras perspectivas.

A primeira abordagem (I), tanto do ponto de vista lógico como cronológico, diz respeito às análises cientificas voltadas à avaliação do risco, nas quais o risco é concebido em termos da "probabilidade quantificável de um resultado histórico adverso" ${ }^{18}$. Os métodos de avaliação de risco não deixaram de evoluir com o advento de outras abordagens mais complexas, que trouxeram contribuições substanciais de diversas ciências sociais. Contudo, observa-se que este registro nunca se afastou da sua finalidade original de avaliar probabilidades e produzir resultados quantificáveis, para finalidades práticas e aplicadas. A “análise de riscos", explica Ayala Carcedo $^{19}$, é uma disciplina integradora e sintética, porque tem como escopo a obtenção de resultados objetivos, mensuráveis, que servem como subsídio para a gestão de riscos (risk management) em diversas áreas de aplicação, como no setor financeiro, e mesmo em áreas médicas.

A segunda (II) é a abordagem socioconstrucionista que tem como referência fundamental o trabalho da antropóloga Mary Douglas ${ }^{20}$. Aqui, a subdisciplina percepção do risco não recorre apenas às ciências exatas, mas também à ecologia e às ciências cognitivas, bem como às ciências sociais em geral (sobretudo a antropologia), com o propósito de integrar as descrições objetivas das disciplinas científicas

\footnotetext{
${ }^{14}$ Cf. SILVEIRA, Clóvis Eduardo Malinverni da. Uma breve análise sobre a integração entre as dimensões científica e axiológica na construção do risco ambiental. Revista Eletrônica Direito e Política, Programa de Pós-Graduação Stricto Sensu em Ciência Jurídica da UNIVALI, Itajaí, v.8, n.1, 1 quadrimestre de 2013. Disponível em: www.univali.br/direitoepolitica - ISSN 1980-7791.

15 GUIVANT, Julia S. A trajetória das análises de risco: da periferia ao centro da teoria social. Disponível em: <http://www.iris.ufsc.br/pdf/trajetoriasdasanalises derisco.pdf $>$. Acesso em: 17 de março de 2011. Também publicado na Revista Brasileira de Informações Bibliográficas - ANPOCS. № 46, 1998, p. 3-38.

${ }^{16}$ MARANDOLA JR, Eduardo; HOGAN, Daniel Joseph. O risco em perspectiva: tendências e abordagens. In: GEOSUL: Revista do Departamento de Geociências da Universidade Federal de Santa Catarina. Centro de Filosofia e Ciências Humanas. v. 19, n. 38 , jul./dez 2004. Semestral. ISSN 0103-3964. Florianópolis: Editora da UFSC, 2004. 246 p., p. $25-58$.

${ }^{17}$ ACOSTA, Virgínia García. El Riesgo como construcción social y La construcción social de riesgos. Desacatos. Septiembrediciembre, n. 19. Centro de Investigaciones y Estudios en Antropologia Social. Distrito Federal, México, 2005, p. 11-24.

${ }^{18}$ JASANOFF, Sheila. Direito. In: JAMIESON, Dale (coord.). Manual de Filosofia do Ambiente. Tradução de João C. Duarte. Lisboa: Instituto Piaget, 2005 [2003], p. 342-343.

${ }^{19}$ AYALA-CARCEDO, Francisco Javier. Introducción al análisis y gestión de riesgos. In: AYALA-CARCEDO, Francisco Javier; CANTOS, Jorge Olciona (orgs.). Riesgos Naturales. Barcelona: Ariel, 2002, 1516p. (133-146), p. 133.

${ }^{20}$ DOUGLAS, Mary. Risk aceptability according to the social sciences. New York: Routledge, 2003 [1985], 126 p; DOUGLAS, Mary. Risk and Culture. Berkeley; Los Angeles: University of California Press, 1982, 221 p.
} vol.08, no. 03, Rio de Janeiro, 2015.pp. 1913-1948 
com a percepção cultural, pública e individual, dos riscos ${ }^{21}$. A tese central, nesta perspectiva, é a de que a percepção do risco e, por conseguinte, seus respectivos níveis de aceitação, são construídos coletivamente, de modo semelhante à linguagem e aos juízos estéticos, conforme as especificidades de cada ambiente social e cultural. Deste modo, o risco torna-se um "produto conjunto de conhecimento e aceitação" 22 , e não apenas uma probabilidade a ser mensurada. Esta perspectiva transcende o objetivismo das "análises de risco" usuais e insere a subjetividade e os contextos culturais como elementos indissociáveis da noção de risco (já que todo risco é necessariamente uma percepção de risco ${ }^{23}$. Essa perspectiva prenuncia o trabalho dos teóricos da sociedade de risco, como Ülrich Beck e Anthony Giddens.

A terceira abordagem (III) não deriva da anterior, senão que evolui de maneira paralela, e também concebe o risco como um objeto construído, porém em um sentido bastante diverso: Acosta trabalha de maneira muito acurada as diferenças entre as duas linhagens teóricas marcadas por um caráter "construtivo", que podem ser designadas "o risco como construção social", de um lado, e "a construção social de riscos", de outro. Não se trata mais, neste último caso, de avaliar a forma pela qual as percepções de risco são construídas a partir de cada contexto sociocultural, e sim de colocar a ênfase no caráter antrópico ${ }^{24} \mathrm{da}$ produção das situações de risco, ou seja, no fato de que os riscos são criados ou potencializados de diferentes maneiras pela ação humana. Por outras palavras, a questão não é evidenciar que a percepção do risco é um produto complexo de conhecimento e aceitação, e sim que as situações de vulnerabilidade, bem como as mazelas sociais em geral, são produzidas por uma confluência de fatores naturais e de fatores sociais - e, nesse sentido, decorrem de um sem-número de razões de ordem econômica, política, jurídica, demográfica, dentre outras. Estas razões que devem ser objeto de investigação autônoma, a fim de que se compreenda como são produzidas as ameaças e as situações, ditas de vulnerabilidade, em que se encontram determinados grupos sociais, comunidades, classes, indivíduos.

Paulatinamente, as ciências naturais e sociais foram reconhecendo que desastres antes atribuídos a causas naturais frequentemente têm como origem ou como fator catalizador determinadas práticas humanas, tais como a degradação ambiental e os processos de urbanização que produzem segregação socioespacial. Estes enredos estão fortemente marcados por desigualdades socioeconômicas, desde o plano local até o global. Nesse sentido, entende Acosta, é que autores como Keneth Hewitt, Allan Lavell, Georgina Calderón e Anthony Oliver-Smith problematizam a "construção social do desastre" ou "construção social da vulnerabilidade" ${ }^{25}$. Muito embora as ciências naturais tenham tornado mais sofisticado o tratamento

\footnotetext{
${ }^{21}$ DOUGLAS, Mary. Risk aceptability according to the social sciences. New York: Routledge, 2003 [1985], p. 22.

${ }^{22}$ ACOSTA, Virgínia García. El Riesgo como construcción social y La construcción social de riesgos. p. 15-16.

${ }^{23}$ MARANDOLA JR, Eduardo; HOGAN, Daniel Joseph. O risco em perspectiva: tendências e abordagens. p. 33.

${ }^{24}$ Id, p. 33-34.

${ }^{25}$ ACOSTA, Virgínia García. El Riesgo como construcción social y La construcción social de riesgos. p. 16-17.
} _vol.08, nº. 03, Rio de Janeiro, 2015.pp. 1913-1948 
objetivo dos riscos, explica Maskrey, foram as ciências sociais que permitiram o desenvolvimento do conceito de vulnerabilidade, pelo qual tornam-se explícitas as diferenças entre populações e grupos sociais, no que tange a suas capacidades de absorver e recuperar-se de eventos danosos. Esta capacidade relativa resulta de uma série de processos não naturais, sobretudo de ordem socioeconômica, produtores de estados de vulnerabilidade que serão objeto de denúncia no âmbito das ciências sociais ${ }^{26}$.

Tanto a segunda como a terceira perspectivas referidas acima conferem ao risco um caráter mais polissêmico e interdisciplinar do que na análise de riscos tradicional. Isso abre a possibilidade de uma maior integração entre os componentes ditos objetivos e subjetivos, bem como entre os fatores ditos naturais e antrópicos, ou ainda entre os conteúdos ditos científicos e axiológicos. Sem dúvida, busca-se, contemporaneamente, uma maior convergência do conhecimento produzido nas mais diversas disciplinas (e por diferentes marcos teóricos) para o enfrentamento de problemas determinados. Maskrey ${ }^{27}$ entende que a temática do risco vive um momento "holístico", referindo-se a esta tentativa de integração entre abordagens antes isoladas. Isso ocorre tanto no meio acadêmico como nos processos decisórios.

Hoje, esclarece Veyret, o risco não constitui um campo específico de estudos, ou uma aplicação específica no contexto desta ou daquela área do conhecimento, e sim uma abordagem transversal, pela qual se integram aportes das ciências "duras" com os aportes da sociologia, da antropologia, da economia e do direito, dentre outras. Esta integração é de fundamental importância, tendo em conta a superação da ideia de que riscos podem ser mensurados objetivamente: enquanto percepção de um perigo, um risco só existe para o indivíduo ou grupo "que o apreende por meio de representações mentais e com ele convive por meio de práticas específicas" ${ }^{28}$. Entretanto, as mazelas sociais, sejam atuais ou futuras, não existem sem que sejam produzidas por uma confluência de fatores naturais e humanos/sociais, independentemente da forma como são percebidas ou enfrentadas.

A obra de Beck (e algo semelhante pode ser dito a respeito de Giddens) ocupa uma posição de destaque neste percurso, uma vez que a noção de risco é situada, pelo sociólogo alemão, no centro da teoria social ${ }^{29}$. Se antes o risco aparecia como uma variável dentre outras, ele acaba por se tornar, em Beck, a noção fundante de uma abrangente teoria da sociedade moderna. ${ }^{30}$ Por outras palavras, explica Guivant que o objeto risco é tomado como "chave de compreensão" das características, limites e transformações do projeto de modernidade,

\footnotetext{
${ }^{26}$ MASKREY, Andrew. El Riesgo. p. 14 e ss.

${ }^{27}$ MASKREY, Andrew. El Riesgo. In: MASKREY, Andrew (org.). Navegando entre brumas. La aplicación de los sistemas de información geográfica al análisis de riesgos en América Latina. Bogotá: Intermediate Technology Development Group (ITDG)/Red de Estudios Sociales en Prevención de Desastres en América Latina - RED, 1998, p. 20-26.

${ }^{28}$ VEYRET, Yvette (org.). Os riscos: o homem com agressor e vítima do meio ambiente. Tradução Dilson Ferreira da Cruz. 1 ed. São Paulo: Contexto, 2007, p 11.

${ }^{29}$ MARANDOLA JR., Eduardo; HOGAN, Daniel Joseph. O risco em perspectiva. p. 23.

${ }^{30}$ GOLDBLATT, David. Teoria Social e Ambiente. Tradução Ana Maria André. Lisboa: Instituto Piaget, 1998, p. 228. vol.08, n. 03, Rio de Janeiro, 2015.pp. 1913-1948 
como o mecanismo de reprodução social par excellence da chamada segunda modernidade, que é o eixo sobre o qual deverá ser estruturada a cultura e a política do futuro. Esta elevação do objeto risco também resulta em uma espécie de "ecologização da teoria social" ${ }^{31}$, já que o risco arquetípico de Becké, claramente, aquele que diz respeito à catástrofe ecológica, muito embora a intenção do autor seja explicar e projetar a sociedade como um todo.

Contudo, note-se que essa preocupação original de Beck acaba por sobredeterminar seus estudos posteriores, de modo que, ainda que ele tenha refletido e escrito sobre problemas urbanos e a emergência de movimentos sociais, seu aparato teórico ainda é, essencialmente, aquele pensado para enfrentar questões como a possibilidade das catástrofes nucleares, o aquecimento global e o envenenamento dos ecossistemas e da saúde humana pelo agrobusiness (e, mais recentemente, questões bem peculiares como a do terrorismo).

Pode-se afirmar que especificidade teórica de Beck reside no grau de importância conferida ao risco enquanto principal chave explicativa da teoria social, e é isso que permitiria, eventualmente, falar em um quarto registro (IV) nas referidas abordagens sobre o risco, nas classificações acima referidas (dentre outras semelhantes). Entretanto, pode-se argumentar também que a concepção de risco, no contexto da sociedade de risco, está mais em uma relação de continuidade com a segunda matriz referida do que na raiz de uma perspectiva completamente autônoma, e que ela é pouco aparelhada teoricamente para o enfrentamento das preocupações da terceira matriz referida. Esta afirmação é polêmica, mas é plausível quando, por analogia, se considera a imensa lacuna entre as linhagens teóricas II e III, ou seja, a diferença de propósitos e de métodos entre a pesquisa do "risco como construção social" e a pesquisa da "construção social de riscos", para utilizar as expressões de Acosta.

Nesta direção, Acosta ${ }^{32}$ pontua que o conceito de construção social do risco tende a ser utilizado de maneira quase exclusiva, dentre os autores europeus, sob o enfoque da relatividade temporal e espacial das percepções de risco; do risco como híbrido de conhecimento e aceitação e, portanto, como constructo cultural. Não obstante as especificidades de sua obra, Beck pode ser situado no contexto do legado teórico iniciado por Douglas. Cada sociedade produtora de riscos constrói socialmente (uma percepção) (d)estes riscos: a operação fundamental, neste contexto teórico, é problematizar tal construção social do risco tendo em conta "o tipo de sociedade da qual emana, de suas crenças e visões dominantes". ${ }^{33}$

Por outras palavras, há uma verdadeira lacuna entre o problema da percepção dos riscos e o problema da produção das condições de vulnerabilidade social e individual em face de problemas naturais ou sociais, ou ambos. Ao colocar o risco como conceito central para compreensão do mundo social, Beck o

\footnotetext{
${ }^{31}$ GUIVANT, Julia S. A tragetória das análises de risco. p. 3-38.

${ }^{32}$ ACOSTA, Virgínia García. El Riesgo como construcción social y La construcción social de riesgos. p. 15-16.

${ }^{33}$ ACOSTA, Virgínia García. El Riesgo como construcción social y La construcción social de riesgos. p. 16. vol.08, nº. 03, Rio de Janeiro, 2015.pp. 1913-1948
} 
faz privilegiando a matriz II, condizente com sua concepção de modernidade reflexiva. O problema da matriz III é enfrentado tardiamente, em suas últimas obras; mesmo assim, argumenta-se, o estudo da conformação das vulnerabilidades sociais aparece como uma variável no seio daquele estudo dos processos pelos quais as percepções culturais são reflexivamente mediadas. Desta maneira, as preocupações da matriz III são assimiladas pelas preocupações da matriz II.

\section{O CARÁTER EXCESSIVO DO TEMA DA REFLEXIVIDADE NA TEORIA DA SOCIEDADE DE RISCO}

Seja nas suas primeiras obras, quando a questão distributiva dos riscos é minimizada em face do efeito equalizador das ameaças da segunda modernidade, até as obras mais recentes, quando a questão distributiva assume maior relevância, o enfoque de Beck é claramente predeterminado pelo tema da construção social do risco na acepção dita culturalista, que põe o acento nas percepções e nas relações de definição em torno dos riscos civilizatórios. Isso é particularmente evidente no conceito de modernidade reflexiva, em torno do qual gravitam diversos outros temas. Desde quando Beck anuncia que, na primeira modernidade, a lógica da produção de riquezas domina a lógica da produção de riscos, e que, na sociedade de risco, essa relação se inverte (pois, com a "reflexividade dos processos de modernização" as forças produtivas perdem sua "inocência" ${ }^{34}$ ), resta evidente sua preocupação maior com o problema da convergência entre fatos objetivos e uma determinada percepção, social e culturalmente determinada, sobre o risco.

À parte o fato de que os riscos da segunda modernidade possuem uma maior abrangência espacial e temporal (i. e., são globais, transgeracionais, cumulativos, sinergéticos, tendencialmente invisíveis ou não rastreáveis), o aspecto determinante do raciocínio é que estes riscos vão se tornando progressivamente mais perceptíveis, e sua administração mais autoconsciente, o que traduz justamente o advento da modernidade reflexiva. Diversos temas caros ao autor podem ser entendidos como desdobramentos do problema da reflexividade: o modo como as instituições político-jurídicas procuram ocultar estes riscos (questão da irresponsabilidade organizada); o papel do conhecimento científico e dos experts nas relações de definição sobre o risco; a defesa de um cosmopolitismo metodológico em detrimento de um nacionalismo metodológico; os efeitos da sociedade de risco e dos processos de individuação da segunda modernidade sobre os elementos constitutivos da sociedade industrial (por exemplo, sobre o "esquema de classes", o "trabalho assalariado" e a "família nuclear"); e assim sucessivamente.

\footnotetext{
${ }^{34}$ BECK, Urich. Sociedade de risco: rumo a uma outra modernidade. Tradução Sebastião Nascimento. São Paulo: Ed. 34, 2010, p. $15-16$.
} 
As cinco teses de Beck sobre "a arquitetura social e a dinâmica política" desta "autoameaça civilizatória", resultante não do fracasso e sim do êxito da modernidade, refletem, de maneira coerente, a mesma mediação reflexiva.

A primeira tese ${ }^{35}$ compreende que os danos desencadeados pelo desenvolvimento das forças produtivas, que frequentemente são "irreversíveis" e permanecem "invisíveis", estão sempre "abertos a processos sociais de definição" por intermédio do conhecimento (científico ou anticientífico) que se tenha deles; e sempre e somente por esta via reflexiva podem ser alterados, diminuídos, dramatizados ou aumentados. Embora o argumento seja válido em si, não pode ser superestimado, sob pena de se obscurecerem outros aspectos fundamentais da investigação sociológica (bem como da reflexão teórico filosófica). Por exemplo, o fato de que os danos da modernidade estejam abertos a processos sociais de definição não significa que a compreensão destes processos sociais de definição seja suficiente para a compreensão dos processos sociais que se encontram na origem desses danos; ou que combate r esses danos requeira, sempre e tão somente, atuar sobre seus processos sociais de definição, e não, por exemplo, sobre imperativos econômicos, ou mesmo sobre imperativos políticos, ideológicos ou culturais não transparentes/reflexivos.

A segunda tese ${ }^{36}$ é a do chamado "efeito bumerangue": os riscos da modernização "cedo ou tarde acabam alcançando aquele que os produziram ou que lucram com eles". Os ricos e poderosos, assim como as pessoas comuns, também não estão seguros diante deles. Este é um argumento válido para determinadas espécies de riscos (quando se considera, por exemplo a ameaça nuclear), mas negligencia claramente as posições e interesses de classe (ou de riqueza, de posição social, etc.) que se encontram não apenas na origem das relações de definição sobre o risco, senão também na raiz mesma dos perigos criados pela modernidade. Os riscos da contemporaneidade estão, de fato, sujeitos a relações sociais de definição; não obstante, a explicação sobre o advento destes riscos não reside apenas na compreensão de suas relações sociais de definição.

A terceira tes $\mathrm{e}^{37}$ é a do caráter autorreferencial (com proximidade da autopoiese de Niklas Luhmann) da economia, e pode ser resumida na seguinte sentença: "com a canibalização econômica dos riscos que são desencadeados através dela [a economia], a sociedade industrial produz as situações de ameaça e o potencial político da sociedade de risco". Entretanto, esse caráter autorreferencial da economia esconde um determinado conteúdo ideológico frequentemente subestimado. Convém perguntar porque a sociedade industrial canibaliza economicamente os riscos desencadeados - porquê, em todo caso, haveria de ser assim.

\footnotetext{
${ }^{35}$ Id., p. 27.

${ }^{36}$ Id., p. 27.

${ }^{37}$ Id., p. 28.
} 
Pela quarta tese ${ }^{38}$ argumenta-se que, em termos civilizatórios, os riscos são atribuídos (e não possuídos, como no caso das riquezas), de modo que "o potencial político da sociedade de risco tem de se desdobrar e ser analisado numa sociologia e numa teoria do surgimento e da disseminação do conhecimento sobre os riscos". O argumento tem um momento de verdade, mas é demasiado unilateral, conforme argumentos da seção anterior: seja (i) porque ignora problemas sociais que não podem ser caracterizados como riscos; seja (ii) porque sugere-se contemplar (e trabalhar criticamente na administração dos) riscos apenas sob a faceta da percepção de riscos, e não sobre os processos não necessariamente reflexivos que dão causa à proliferação destes riscos.

A quinta tese ${ }^{39}$ é a da disputa definitória em torno dos riscos: na sociedade de risco, as catástrofes recebem um peso político, pois sua prevenção e manejo (assim como a prevenção e manejo dos efeitos colaterais dos riscos, sejam econômicos, políticos, sociais, culturais) requerem uma verdadeira "reorganização do poder e da responsabilidade". Esta tese, por fim, é de grande relevância para a sociologia do risco - o problema surge, sustenta-se, na medida em que o argumento é extrapolado, obscurecendo outros fatores igualmente importantes para o estudo do social. No limite, o estudo das origens e do significado das mazelas sociais limita-se ao estudo sobre as disputas definitórias em torno da realidade das catástrofes futuras e do modo pelo qual devem ser enfrentadas.

Conquanto essas teses tenham sido, posteriormente, objeto de novos desdobramentos, ocasionalmente de maneira autocrítica ${ }^{40}$, elas sobrevivem, em sua essência, a toda a obra de Beck. De maneira explícita ou implícita, as construções argumentativas são sempre mediadas pelo mencionado caráter reflexivo da sociedade de risco. Contudo, isso que constitui importante descoberta para certas finalidades pode, ao cabo, criar dificuldades para outras. Argumenta-se que, muito embora a abordagem culturalista seja bastante rica e útil (e, portanto, não constitua, em absoluto, um problema em si), ela resulta demasiado particular e unilateral no contexto da obra de Beck, uma vez que o sociólogo pretende formular uma teoria compreensiva dos problemas da sociedade contemporânea (ou da modernidade reflexiva), não apenas investigando as razões de suas mazelas, como também matizando as condições e possibilidades de seu porvir.

É nesta mesma direção que Acosta ${ }^{41}$ propõe uma síntese entre as duas matrizes autônomas (abordagens II e III, conforme convencionado neste texto) que problematizam o caráter construído do risco: uma com ênfase no caráter "culturalista", que parte da preocupação sobre como a sociedade vê os riscos (sempre com lentes calibradas a partir de suas determinações culturais); e outra visão mais

\footnotetext{
${ }^{38}$ Id., p. 28.

${ }^{39}$ Id., p. 28.

${ }^{40}$ Cf. BECK, Ulrich. World at risk. Translated by Ciaran Cronin. Cambridge: Polity Press, 2009, 269 p., p. 160-186 (capítulo 10).

${ }^{41}$ ACOSTA, Virgínia García. El Riesgo como construcción social y La construcción social de riesgos. p. 22. vol.08, nº. 03, Rio de Janeiro, 2015.pp. 1913-1948
} 
"socioeconômica", com ênfase na gênese das situações de vulnerabilidade que sujeit am os grupos sociais aos mais diversos males, muito especialmente no contexto da América Latina:

La síntesis de los enfoques teóricos que hemos revisado [...] se vincula con la necesidad de responder a varias perguntas. ¿Por qué la percepción del riesgo no coincide, en muchas ocasiones, con el análisis real de la vulnerabilidad de las sociedades que han construido socialmente el riesgo en el que viven? ¿Cómo se vincula esta percepción del riesgo con la sistemática contrucción de riesgos materiales? ¿De qué manera la percepción del riesgo puede incidir el na deconstrucción de riesgos? Se trata de retos teóricos sobre los cuales tenemos que reflexionar, a partir de acercamientos a la realidad empírica, y enriquecer con ello nuestras consideraciones al tema de los desastres. Podemos decir que la idea central del planteamiento culturalista es que el hombre o, en su caso, la sociedad, ve los riesgos a través de lentes calibrados a partir de sus determinaciones culturales. La visión que parte del énfasis en variables socioeconómicas hace referencia a los imaginarios formales, que han provocado verdaderos desencuentros en los modelos de prevención y manejo de desastres, particularmente en América Latina y el resto de los países de menor desarollo realtivo. ${ }^{42}$

Para Acosta, estas abordagens não são antitéticas; são antes complementares. Se a percepção de riscos é dada culturalmente, os riscos são construídos porque resultantes de determinados condicionantes históricos e espaciais, também em processos não mediados por um caráter reflexivo. Daí a centralidade do tema da ideologia ao longo das tradições críticas, que problematizam a forma como os conteúdos são individualmente e socialmente representados. As abordagens integradoras trabalham sobre o pressuposto da viabilidade e da utilidade da conjugação das potencialidades destas matrizes teóricas em uma compreensão científica das práticas dos grupos sociais e das comunidades.

A teoria da sociedade de risco não desempenha (a menos não de maneira equilibrada) esse papel integrador, o que não seria um problema desde que a teoria não fosse tão abrangente em seus propósitos. $\mathrm{O}$ enfrentamento do tema da desigualdade na distribuição dos riscos e na produção das situações de vulnerabilidade, até mesmo nas obras tardias de Beck, aind a não atesta a persecução deste desafio integrador. O problema da reflexividade fixa os parâmetros de toda investigação e condiciona seu enfoque. De resto, ao conceituar precocemente a sociedade de risco por oposição à sociedade de classes, Beck desfaz o diálogo com importantes tradições teóricas cujas ferramentas conceituais poderiam aprimorar seus diagnósticos sobre a sociedade contemporânea. Sustenta-se que a teoria da sociedade de risco apresenta limitações a esse respeito, as quais aparecerão com notável clareza em temas como a segregação e os conflitos sociais urbanos, onde é fundamental perscrutar os processos situados na origem das mazelas que vão explicar o advento dos movimentos sociais contestatórios.

${ }^{42}$ Id., p. 22. 
É insuficiente compreender os problemas contemporâneos (ao menos sob a rubrica da produção e da distribuição de riscos) pelas lentes do seu caráter reflexivo, porque importa saber não apenas como os riscos são percebidos, e sim como como os riscos são produzidos, em razão de processos sociais irrefle tidos, e ideologicamente negados ou (re)interpretados. É crucial questionar que forças econômicas, políticas e de posição social atuam na produção das situações de vulnerabilidade e nos problemas socioambientais crônicos, antes mesmo que estas condições possam ser percebidas, mitigadas ou legitimadas no plano político/jurídico, pela percepção cotidiana ou pelo senso comum teórico vigente nos espaços acadêmicos. Enfim, a (re)produção dos estados de vulnerabilidade social deve também ser compreendida a partir dos seus processos constitutivos, à parte sua mediação por processos sociais de definição, caso em que é mais frutífero descer "à raiz do problema, à base mesma que explica os processos de desastre" ${ }^{43}$. Evidentemente, a produção das mazelas sociais é mediada por processos sociais de definição, na medida em que são descritas, distribuídas, assumidas ou negadas. Daí não decorre que os problemas sejam, sempre e antes de tudo, problemas de disputas de definição sobre o risco; ou mesmo que os problemas sociais (como a questão dos conflitos no cenário urbano) sejam, sempre e tão somente, problemas de percepção e gerenciamento de riscos.

Sobre este último ponto, e sob o enfoque jurídico, é interessante notar que muitos danos causados ao meio ambiente urbano, bem como à saúde humana, simplesmente não se prestam às análises ou percepções de risco - seja por constituírem problemas bem conhecidos em sua gravidade e dimensão, seja por não comportarem incertezas, dubiedades ou um registro probabilístico. Grande parte dos problemas associados à negação de direitos sociais e/ou ambientais são problemas substancialmente atuais e crônicos, bastante conhecidos em suas consequências, mas muito mal compreendidos em seus processos constitutivos. Só faz sentido falar em riscos de ameaças futuras, tal como se apresentam a um dado observador (indivíduo ou instituição). O próprio Beck faz essa ressalva repetidamente ao longo de sua obra; não obstante, parece supervalorizar a noção de risco, ao concebê-lo como chave-mestra de explicação do mundo social. O risco se torna um conceito onipresente; enxerga-se todo problema social como resíduo de uma disputa definitória em torno de percepções subjetivas (individuais, coletivas ou institucionais) a respeito de catástrofes futuras incertas ou controversas.

Em estudo que promove um balanço crítico de diversas pesquisas de campo (no duplo sentido de pesquisas sociológicas/geográficas e jurídico-documentais) vinculadas a um mesmo eixo de investigação, Caubet sustenta que "a noção de risco está abusivamente utilizada para justificar iniciativas e

\footnotetext{
43 "La construcción social del riesgo que parte de un enfoque alternativo para el estudio de los desastres se refiere a la raíz del problema, a ala base misma que explica los processos de desastre”. Id. p. 23.
} 
empreendimentos em relação aos quais não existe dúvida que resultarão em danos". Com grande frequência, no plano jurisdicional ou administrativo, acontecimentos social e ecologicamente funestos são:

Acoimados do qualificativo "risco" quando, na realidade, não configuram nem comprovam a hipótese de risco pelo fato de estarem totalmente fora da noção de incerteza; o evento afirmado como sendo "de risco" não o é, pois sua ocorrência só está indeterminada [tal como no exemplo citado] quanto ao momento futuro em que necessariamente ocorrerá ${ }^{44}$

Assim, a preocupação em torno do modo pelo qual os riscos são percebidos ou encenados pode ser entendida como unilateral, porquanto recusará investigações mais aprofundadas sobre o modo como os riscos são originados - mas também, e sobretudo, como se constituem as mazelas e os conflitos sociais crônicos e estruturalmente incompatíveis com a noção de risco. Ou seja, diversos problemas urbanísticos não podem ser conceituados em termos de desastres/danos de ocorrência futura e incerta, cuja realidade, dimensão e relevância serão, por este motivo, disputadas por diferentes modos de percepção. É certo que problemas sociais e ambientais crônicos podem, em certo sentido, ser objeto de disputas de definição; à parte isso, entretanto, sua própria existência, concreta e atual, consiste em importante objeto de estudo das ciências sociais.

Em dadas situações caberia perguntar, por exemplo, quais são os processos sociais mais decisivos e que forças agem na conformação e no agravamento dos problemas sociais urbanos; que fatores políticos, econômicos ou institucionais explicam as situações de vulnerabilidade dos grupos sociais (vulnerabilidades que Maskrey ${ }^{45}$ classifica como físicas, econômicas, sociais, políticas, técnicas, ideológicas, culturais, educativas, ecológicas e institucionais, dentre outras). No contexto do presente escrito, particularmente, caberia também perguntar quais processos encontram-se na raiz dos antagonismos sociais e ambientais contemporâneos e que, independentemente da forma como são percebidos, negados ou confrontados, resultam nas já conhecidas mazelas constituintes do cenário urbano.

\section{A ReVOlta DA DESigualdade AOS OlHos DE ÜLRich BECK E A ONIPRESENÇA DA MEDIAÇÃO REFLEXIVA}

De que modo seria possível compreender esses movimentos urbanos de caráter (pré-) revolucionário sob a ótica de Ülrick Beck e das categorias centrais da teoria da "sociedade de risco"? Tal interrogação permite uma série de enfoques, cujos relevantes desdobramentos certamente merecem estudos mais sistemáticos. Para a reflexão ora proposta, será de grande proveito a referência ao artigo de opinião intitulado La revolta de la

${ }^{44}$ CAUBET, Christian. O conceito de sociedade de risco como autoabsolvição das sociedades industriais infensas à responsabilidade jurídica. Cadernos de Direito. Piracicaba, v. 13 (24): 63-84. Jan./jun. 2013. Disponível em: $<$ https://www.metodista.br/revistas/revistas-unimep/index.php/direito/article/viewArticle/ 1204>. Acesso em 15.04.2015, p. 78.

${ }^{45}$ MASKREY, Andrew. El Riesgo..., p. 14-18. 
desigualdad ${ }^{46}$, publicado no El País de 4 de maio de 2009, texto bastante representativo do pensamento do autor sobre a matéria e que remete, de maneira implícita ou explicita, a tópicos e conceitos nucleares, que perpassam sua obra escrita.

Pela expressão "revolta contra as desigualdades" Beck ${ }^{47}$ designa as recentes e explosivas insurgências urbanas marcadas por três principais fatores causais: (i) o "desacoplamento entre rendimento e ganância"; (ii) a "contradição entre legalidade e ilegalidade"; e (iii) "as expectativas mundiais de igualdade". Inicialmente, Beck comenta que, no contexto da modernidade reflexiva, cresce a consciência e a indignação contra os privilégios das elites globais: aqueles que exercem o controle das finanças mundiais são depreciados publicamente, "executados, ao menos moralmente, nos debates televisivos". O fato de que essa consciência resulte na insurgência de legiões de indignados contra os privilégios é bastante plausível. Entretanto, a explicação acerca desse saber reflexivo não esclarece sobre as raízes dos privilégios, como eles são possíveis ou mesmo necessários a fim de consolidar e reproduzir uma dada ordem social; que dinâmicas estruturam este mercado financeiro globalizado, que antagonismos the são intrínsecos; qual o papel das estruturas políticas e jurídicas, em associação com dados imperativos econômicos.

O problema com essa "execução moral" dos privilégios sem mérito reside justamente no fato de que essa execução é tão somente moral. Utiliza-se aqui, de maneira proposital, a expressão privilégios sem mérito, tendo em vista o mal disfarçado discurso meritocrático fortemente presente no linguajar político, midiático e cotidiano. Pressupõe-se, no seio desse discurso, que a miséria de contingentes cada vez maiores pode ser justificada tão somente na falta de criatividade, de persistência ou atitude empreendedora; que resulta, trocando em miúdos, de uma condição ou predisposição individual. A análise do discurso é bastante frutífera neste particular, ao explicitar que o discurso meritocrático pode tantas vezes funcionar como vetor de privilégios, enquanto o discurso contra a desigualdade, a depender do contexto, pode visar menos a igualdade como resultado do que o autêntico respeito ao merecimento individual. Em tese, o que pretende o discurso da criação de "oportunidades", ou mesmo o princípio da discriminação compensatória, senão coroar aquele mérito que teria sido obstado injustamente por uma condição original de desequilíbrio?

Acerca da condenação moral da ganância, convém levantar a questão da tão disseminada lifestyle ecology, que ilustra o quão eficiente pode ser o ideário dominante no propósito de, sempre mais uma vez, recolocar suas fundações a partir de suas próprias inconsistências (por exemplo, justificar um empreendedorismo predatório no discurso da sustentabilidade). Papel semelhante é desempenhado pelo discurso (no mais das vezes

\footnotetext{
${ }^{46}$ BECK, Ülrich. La revuelta de la desigualdad: El enriquecimiento rápido convirtió a muchos en dependientes de la droga del dinero prestado. Ahora los ricos poseen un poco menos, pero a los pobres no les alcanza para vivir. La situación es (pre)revolucionaria. El País. Madri. 04 maio 2009. Disponível em: <http://elpais.com/diario/ 2009/05/04/opinion/1241388011_850215.html>. Acesso em: 15 mar. 2015. Documento não paginado. ${ }^{47}$ Ibid.
} 
bem-intencionado e coerente) da participação do cidadão nos processos de gestão democrática do espaço urbano. Apesar de seu potencial subversivo, a temática ecológica e a temática da democracia participativa encontram-se tão plenamente adaptadas ao status quo que, longe de constituir um óbice ao crescimento econômico ilimitado e insustentável, atuam como mola propulsora da condição ultraliberal na sociedade mundial do risco. O consenso político-econômico promove sistematicamente a privatização dos recursos, a progressiva concentração de ganhos e a socialização dos prejuízos do progresso. No limite, a própria crítica ao sistema econômico capitalista e à crise das estruturas políticas funcionam, contemporaneamente, como combustível da ideologia de livre mercado que, extremamente plástica, flexível, adaptável, pode absorver as mais variadas censuras de ordem moral, incluindo a crítica ecológica, a crítica da desigualdade social, a crítica do egoísmo consumista, e assim sucessivamente. Isso desde que o big business esteja acima de qualquer controle ético, político ou jurídico.

No contexto de desmoronamento das finanças mundiais, Beck ${ }^{48}$ reconhece e deplora o aumento da desigualdade tanto no marco nacional quanto no global. Observa, de maneira pertinente, que o aumento fabuloso (obsceno?) da riqueza de poucos atenta contra todo princípio de legitimidade e que, no entanto, realiza-se, no mais das vezes, de maneira legal, ou amparada pelas instituições jurídico-políticas - que redunda no prolífico tópico da irresponsabilidade organizada, introduzido no capítulo dedicado ao fatalismo industrial em Ecological Politics in an Age of Risk. Beck argumenta ${ }^{49}$ que na vida cotidiana, na política, na economia e nas ciências, assume-se ingenuamente que os perigos decorrentes do desenvolvimento econômico e industrialtecnológico podem ser administrados e evitados pelos costumeiros critérios da causalidade e da culpa jurídica. Entretanto, é a aplicação das normas que, paradoxalmente, permite que a responsabilidade por problemas sistêmicos não seja atribuída a ninguém, que grandes perigos e desastres sejam "normalizados" juridicamente e cientificamente como "riscos residuais", de modo a estigmatizar eventuais protestos como atos de "irracionalidade". O desenvolvimento deste tópico proporciona um singular espaço de autocrítica para o jurista ${ }^{50}$ : não apenas no sentido usual da crítica da corrupção, do cinismo, do conservadorismo, mas também porque seus melhores esforços podem servir, ao cabo, à reprodução de um sistema garantidor de uma irresponsabilidade cada vez mais bem organizada e generalizada.

Portanto, não se deve jamais subestimar o papel do ilícito na reprodução deste modelo políticoeconômico gerador de catástrofes humanas e naturais, tema que Beck desenvolve de maneira singular. Entretanto, é plausível afirmar que as desigualdades são, em grande medida, encobertas pelas leis vigentes, como atestam as pesquisas jurisprudencial e documental. Beck, que desenvolveu o tema longamente, vê nessa contradição entre

\footnotetext{
${ }^{48} \mathrm{Ibid}$.

${ }^{49}$ BECK, Ülrich. Ecological politics in an age of risk. Translated by Amos Weisz. London: Polity Press, 1995, p. 63-65.

${ }^{50}$ SILVEIRA, Clóvis Eduardo Malinverni. Risco Ecológico Abusivo: a tutela do patrimônio ambiental nos Processos Coletivos em face do risco socialmente intolerável: Caxias do Sul: EDUCS, 2014, p. 84-91.
} 
legalidade e ilegalidade a segunda causa da ira popular ${ }^{51}$. Essa perspectiva é essencial, ao passo que problematiza os mecanismos de legitimação política/jurídica das mazelas sociais; porém será unidimensional se não for acompanhada do enfrentamento teórico dos processos conformadores dos antagonismos sociais de fundo, dos processos subterrâneos dos quais decorrem, em última instância, tais mazelas, cuja realidade será combatida ou assegurada, conforme o caso, pelas instituições jurídicas.

A terceira razão ${ }^{52}$ que Beck cita explicar a emergência global dos movimentos sociais urbanos é a "frustração das expectativas mundiais de igualdade". Ao perguntar como foi possível que, durante um século e meio, a ordem global de desigualdades tenha parecido legítima e estável do ponto de vista das sociedades de bemestar europeias, responde ressaltando a dissimulação instrumentalizada pela perspectiva do Estado-nação. O discurso interno da recompensa pelo esforço, de que qualquer um pode triunfar desde que tenha persistência e criatividade, pode ser entendida como a outra face da cegueira para com a miséria do mundo "externo", situado para além da fronteira nacional (a qual separava as desigualdades politicamente relevantes das irrelevantes). Assim, Beck aponta a contradição flagrante da política das "democracias ricas", que realizam sua pregação pelos direitos humanos nos quatro hemisférios e, simultaneamente, procuram interromper (ou restringir) os fluxos migratórios em face da crescente desigualdade interna, seja por meios jurídicos, políticos ou militares. Exemplificando mais uma vez o argumento da onipresença do tema da reflexividade, a ressalva é que todo o peso da argumentação incide aqui, novamente, sobre as expectativas de igualdade e sua frustração, e não sobre o problema das origens da desigualdade (como essa desigualdade é possível, a que processos sociais responde).

Beck é muito convincente na afirmação de que os problemas sociais/ambientais decorrem do sucesso e não do fracasso da modernidade, e de que a produção de risco moderna tem origem no núcleo do próprio processo de produção de riqueza, de maneira que o problema seria antes de "excesso de produção crônico" ${ }^{53}$, e apenas secundariamente um problema distributivo. Contudo, parece não ter a intenção de explicar os porquês deste excesso de produção crônico - tal como faz, por exemplo, David Harvey, ao derivar do problema da sobreacumulação capitalista o tema da acumulação por espoliação (accumulation by dispossession) ${ }^{54}$. Este excesso de produção seria intrínseco à economia capitalista? Porque isso ocorre e quais são os reflexos disso sobre a vida urbana? Ainda que se trate de tema polêmico, e seja quais forem as hipóteses levantadas, linhas de investigação como essa de Harvey são essenciais. O problema com a teoria da sociedade de risco é que dimensões

\footnotetext{
${ }^{51}$ BECK, Ülrich. La revuelta de la desigualdad: El enriquecimiento rápido convirtió a muchos en dependientes de la droga del dinero prestado. Ahora los ricos poseen un poco menos, pero a los pobres no les alcanza para vivir. La situación es (pre)revolucionaria. El País. Madri. 04 maio 2009. Disponível em: <http://elpais.com/diario/ 2009/05/04/opinion/1241388011_850215.html>. Acesso em: 15 mar. 2015. Documento não paginado.

${ }^{52}$ Id.

${ }^{53}$ GOLDBLATT, David. Teoria Social e Ambiente. Tradução Ana Maria André. Lisboa: Instituto Piaget, 1998, 234-235.

${ }^{54}$ Cf., por exemplo: HARVEY, David. O Novo imperialismo. Tradução Adail Sobral, Maria Stela Gonçalves. 7 ed. São Paulo: Loyola, 2013, 201 p., p. 115-148.
} 
como esta permanecem largamente inexploradas: os problemas sociais são investigados a partir de suas relações de definição, enquanto suas raízes tendem a ser naturalizadas.

Em uma linha semelhante de raciocínio, Goldblatt ${ }^{55}$ afirma que, muito embora Beck descreva com sagacidade "a influência penetrante de um fatalismo industrial que mantém as ficções da sociedade industrial clássica", não dá conta de articular as razões da exacerbação das ameaças e o aumento da percepção social dos riscos; ou, ainda, de explicar porque o impacto combinado destes fatores no comportamento social "é de tal forma decisivo que podemos certamente anunciar a emergência de um novo tipo de sociedade". Os escritos de Beck, assim como, segundo Goldblatt ${ }^{56}$, os de Giddens, permitem formular diversas perguntas importantes: por exemplo, porque os reclames da ciência foram elevados ao patamar de "incerteza epistemológica”, ou porque os processos de individualização e de perda da tradição, associados à modernidade reflexiva, alcançaram um ponto tão alto (e porque isso ocorre justamente a partir dos anos 1980 e 1990); entretanto, a teoria da sociedade de risco não fornece os meios para responder a estas questões.

\section{A TEMÁTICA DA DESIGUALDADE NA SOCIEDADE MUNDIAL DE RISCO, O PROBLEMA DAS RAÍZES SOCIOECONÔMICAS DAS MAZELAS SOCIAIS E A DESPOLITIZAÇÃO DA ESFERA ECONÔMICA}

Ao abordar a questão das demandas recentes por igualdade, Beck ${ }^{57}$ afirma que estas tocam a "autoconsciência do ocidente em seu núcleo neoliberal". O problema, no seu entender, é que o "grito de dor socialista" por igualdade advém do próprio "centro ferido" da sociedade, encontrando repercussão por toda a parte; assim, essa consciência acaba por "alimentar as desigualdades sociais de um modo politicamente explosivo". Ocorre que a consciência das desigualdades as converte em material "conflitivo e inflamável", porque levantam-se expectativas de igualdade que, ao final, serão provavelmente frustradas. Uma vez que o sonho americano (entendido como a promessa de liberdade e igualdade de oportunidades) foi falsificado por promessas cínicas e ideológicas de enriquecimento privado e de disponibilidade ilimitada de combustíveis, e várias sociedades foram convertidas em "dependentes da droga de pedir dinheiro emprestado", Beck pergunta, retoricamente, "onde estão os movimentos sociais que esboçam uma modernidade alternativa". Um projeto de modernidade alternativa passaria pelo advento de novas formas de exploração de energia limpa; requereria um "espírito cívico que supere as fronteiras nacionais" (ponto de vista do cosmopolitismo metodológico) e qualidades como a autocrítica e a

\footnotetext{
${ }^{55}$ GOLDBLATT, David. Teoria Social e Ambiente. Tradução Ana Maria André. Lisboa: Instituto Piaget, 1998, 251-252.

${ }^{56}$ Id., 251-252.

${ }^{57}$ BECK, Ülrich. La revuelta de la desigualdad: El enriquecimiento rápido convirtió a muchos en dependientes de la droga del dinero prestado. Ahora los ricos poseen un poco menos, pero a los pobres no les alcanza para vivir. La situación es (pre)revolucionaria. El País. Madri. 04 maio 2009. Disponível em: <http://elpais.com/diario/ 2009/05/04/opinion/1241388011_850215.html>. Acesso em: 15 mar. 201
}

vol.08, nº. 03, Rio de Janeiro, 2015.pp. 1913-1948 
criatividade, para que se pudesse enfrentar tanto a pobreza quanto as mudanças climáticas, bem como "civilizar os mercados".

Com a queda-livre da crise financeira, entende Beck ${ }^{58}$, ambos - os ricos, que possuem "um pouco menos", e os pobres, que possuem "apenas o suficiente para viver" - saem perdendo, "ainda que não da mesma maneira”. Poder-se-ia argumentar que este diagnóstico é demasiado otimista pois, atualmente, é sabido que os mais ricos apenas ficaram mais ricos durante a crise econômica mais recente. Ademais, a consciência dos especuladores, políticos e lobistas acerca dos riscos criados pelo capital financeiro global não alterou em nada o modo de agir destes atores. O que é decisivo, entretanto, é o modo como o Beck situa (também aqui) todo diagnóstico (e todo prognóstico) acerca do mundo social no plano reflexivo: dentro desta linha de pensamento, importa saber de que modo as sociedades tomam consciência dos seus problemas, que paradoxos e catástrofes disso resultam, que metodologias devem ser adotadas no mapeamento dos riscos e das vulnerabilidades; em síntese, importa compreender os modos pelos quais as sociedades encenam estes riscos e vulnerabilidades.

Este intento foi mais bem trabalhado em World of Risk ${ }^{59}$, uma das obras mais recentes e sofisticadas do célebre sociólogo alemão. Muito embora diversos conceitos já houvessem sido apresentados em obras anteriores - tais como o de cosmopolitismo ${ }^{60}$-, neste livro desenvolve-se a categoria sociedade mundial do risco, que transcende a categoria sociedade de risco, conforme trabalhada nas décadas de 1980 e 1990 . A categoria risco ${ }^{61}$ denota a "realidade controversa do possível", devendo, portanto, ser distinguida tanto da possibilidade meramente especulativa quanto da catástrofe atual. Essa nuance já estava implícita anteriormente, mas é enfrentada de maneira mais direta na produção bibliográfica mais madura. A reflexão sobre a diferença entre as catástrofes realmente ocorrentes e a antecipação do risco permite ao autor avançar no questionamento sobre os modos pelos quais as catástrofes futuras são manufaturadas e sobre os caminhos pelos quais o risco adquire o predicado de real. Ademais, permite investigar as razões pelas quais a antecipação da catástrofe sugere uma reinvenção do político, e como levá-la a efeito.

Em síntese, Beck ${ }^{62}$ trabalha o risco global como encenação/representação da realidade do risco global não no sentido de uma falsificação deliberada da realidade, mas no sentido de que a catástrofe está presente apenas na medida em que o risco é imaginado e representado. Daí a necessidade da reinvenção do campo político, orientada no sentido de dar conta das ações preventivas e precaucionais necessárias à segurança e ao bem-estar

\footnotetext{
${ }^{58}$ BECK, Ülrich. La revuelta de la desigualdad: El enriquecimiento rápido convirtió a muchos en dependientes de la droga del dinero prestado. Ahora los ricos poseen un poco menos, pero a los pobres no les alcanza para vivir. La situación es (pre)revolucionaria. El País. Madri. 04 maio 2009. Disponível em: <http://elpais.com/diario/ 2009/05/04/opinion/1241388011_850215.html>. Acesso em: 15 mar. 2015

${ }^{59}$ BECK, Ulrich. World at risk. Translated by Ciaran Cronin. Cambridge: Polity Press, 2009, 269 p.

${ }^{60}$ BECK, Ulrich. Potere e contrapotere nell'etá globale. Traduzione di Carlo Sandrelli. Roma: Laterza, 2010 [2002]. 455 p.

${ }^{61}$ BECK, Ulrich. World at risk. Translated by Ciaran Cronin. Cambridge: Polity Press, 2009, p. 9-10.

${ }^{62}$ Id., p. 10.
} 
dos cidadãos, superando-se os perigos que decorrem da reflexividade contemporânea do risco. Aqui se amarram as preocupações da obra e, de certo modo, do projeto intelectual de Beck, tais como: o problema da antecipação dos problemas-eventos extremos; a necessária superação da divisão entre experts e leigos, ou entre ciência e política, ou ainda entre objetividade e subjetividade; a problematização da colisão entre diferentes culturas de risco; a necessária adoção de um cosmopolitismo metodológico, para a superação da equação clássica entre sociedade e Estado-nação; etc.

A colisão entre culturas de risco é um dos maiores problemas da política do século XXI, para Beck ${ }^{63}$. Dado que os riscos são imagens especulares das percepções culturais das próprias sociedades que percebem esses riscos, a realidade do risco se mostra justamente pelo seu caráter controverso, pelo julgamento contraditório entre grupos sociais e populações. Uma vez que os riscos globais se tornam "reais" por meio (e em razão) do antagonismo de certezas culturais, uma solidariedade internacional deve emergir. A percepção dos riscos globais, afirma $^{64}$, demanda a institucionalização de um olhar cosmopolita capaz de transpor dificuldades no gerenciamento de perigos marcados por interações complexas (naturais e humanas), com fontes, dinâmicas e efeitos globais. Como fazê-lo, e porque isso na prática não é possível, são questões não respondidas na obra de Beck.

A obra World of Risk representa uma guinada na direção de uma maior valorização de estudos empíricos, bem como na valorização da questão da desigualdade e do problema distributivo dos perigos globais. Beck ${ }^{65}$ fala de uma nova agenda para a teoria sociológica pautada (i) no desacoplamento entre sociedade e Estado-nação; (ii) no abandono da noção de que a sociedade pode ser controlada por alguém; (iii) na conceptualização da modernidade como um processo que carrega dentro de si a semente da autodissolução e da autotransformação, assim como da autorenovação das instituições do Estado-Nação e da sociedade industrial; e (iv) na necessidade de conferir importância central ao desacoplamento temporal, espacial e social entre o "nós" dos tomadores de decisão e o "nós" dos efeitos colaterais. $O$ esboç ${ }^{66}$ de uma teoria social histórico-empírica da sociedade mundial de risco estaria calcado em dois passos principais: (i) a superação metodológica da equação entre Estado-Nação e sociedade; e (ii) uma tipologia das situações de risco desiguais e das dinâmicas de conflito na sociedade mundial do risco.

Esta tipologia culmina ${ }^{67}$ na defesa do cosmopolitismo metodológico que, para Beck, tem se tornado um dos conceitos centrais das ciências sociais (em diferentes contextos, como na pesquisa sobre mobilidade e imigração, estudos pós-coloniais, pós-feminismo e etnografia). Na sociologia, particularmente, entende Beck,

\footnotetext{
${ }^{63}$ Id., p. 12.

${ }^{64}$ Id., p. 161-163.

${ }^{65}$ Id., p. 163.

${ }^{66}$ Id., p. 163.

${ }^{67}$ Id., p. 176.
} 
essas análises estariam cristalizando-se em um novo paradigma que pode ser chamado novo cosmopolitismo. No centro desse paradigma está, por um lado, a pesquisa por novos métodos e estratégias de investigação e, por outro lado, a questão de como os diversos modos sociais de lidar com a diferença refletem nas dinâmicas de desigualdades e de conflitos na sociedade mundial do risco.

É certo que a noção de sociedade mundial de risco logrou atingir um patamar de grande sofisticação, com a clarificação de diversos pontos críticos e a incorporação de temáticas fundamentais como as vulnerabilidades sociais e ambientais, a abordagem empírica e o tema da desigualdade - dentre outros pontos que haviam sido alvo de críticas às obras anteriores. Sem diminuir a riqueza e a proficuidade destes estudos, continua pertinente o argumento inicial desenvolvido nesse texto: de que é problemática a ubiquidade do tema da reflexividade do risco na obra de Beck. Apesar da posterior ênfase no problema distributivo, antes relegado ao segundo plano, a desigualdade global e a vulnerabilidade local são operadas conceitualmente sob a ótica da distribuição de riscos, enquanto a distribuição dos riscos decorre de suas relações sociais de definição, em uma relação claramente circular. Isso fica mais uma vez claro na abordagem da globalidade da sociedade mundial do risco que, para Beck, deve ser construída como um conflito em torno das relações de definição sobre a própria globalidade ${ }^{68}$.

É fato que Beck pergunta, de maneira extremamente pertinente, como as catástrofes são manufaturadas - questão esta que constituía uma visível lacuna na formulação original da teoria da sociedade de risco. As relações entre os diversos atores sociais nessa encenação das relações de definição em torno de riscos e mazelas sociais são analisadas, no âmbito da sociologia do risco, com grande sagacidade. Em obra originalmente publicada em $2002^{69}$, Beck explica como os movimentos de defesa da sociedade civil global atuam simultaneamente como advogados, credores e juízes de determinados valores e das normas globais, promovendo conscientização, alimentando a indignação e a reprovação da opinião pública mundial em face de toda sorte de violações. Faz notar, ademais, que essa defesa realizada por movimentos sociais se encontra limitada por fatores claramente observáveis: por exemplo, os movimentos concentram-se em casos singulares e não têm um inimigo claramente individualizado, contra o qual possam ser endereçados todos os conflitos. Ademais, não se pode falar em uma "linguagem cosmopolita do conflito", e sim em uma confusão de linguagens típicas de cada tipo de conflito (conflitos ecológicos, feministas, religiosos, nacionalistas, sindicais ou em torno de violações de direitos humanos ${ }^{70}$

Ao combinarem estratégias de produção, distribuição e uso estratégico da informação com estratégias de legitimação voltada à fabricação da opinião pública mundial, os movimentos sociais (organizados ou não) posicionam-se em um dos vértices de um triângulo de poder integrado pelo capital e pelo Estado. O domínio

\footnotetext{
${ }^{68}$ Id., p. 186.

${ }^{69}$ BECK, Ulrich. Potere e Contrapotere nell'etá globale. Traduzione di Carlo Sandrelli. Roma: Laterza, 2010 [2002]. 455 p., p. 310.

${ }^{70}$ Id., p. 310.
} vol.08, no.03, Rio de Janeiro, 2015.pp. 1913-1948 1933 
translegal da esfera econômica e também da esfera estatal, que Beck acrescenta aos tipos clássicos de dominação em Max Weber, constitui uma forma intermediária (híbrida) entre dominação legal e ilegal, marcada justamente pela assimetria entre dominação ilegal e legitimação ${ }^{71}$. Os movimentos sociais atuam precisamente encenando e dramatizando a contradição entre a maximização e a perda de legitimidade dessa soberania translegal (poder do qual eles, os movimentos, não participam, porque não estão em posição de tomar decisões coletivamente vinculantes, nem possuem instrumentos econômicos, políticos e militares em seu favor ${ }^{72}$. Por outras palavras, a legitimação dos atores coletivos da esfera civil é sempre precária, uma vez que não eleita nem nominada enquanto tal. Estes atores sustentam-se no sucesso decorrente do desempenho dos papeis autodeclarados de advogados de tais e tais causas. Beck propõe indagar sobre a base de poder dos movimentos avocatórios que é o seu 'capital de legitimação', e distingue a partir daí três tipos de estratégias ${ }^{73}$, que são: (i) a estratégia de dramaturgia do risco; (ii) a estratégia de democratização; e (iii) a estratégia de cosmopolitização, voltada a criar uma esfera pública transnacional.

Beck está perfeitamente ciente de que a economia produz "efeitos colaterais globais" que ameaçam os fundamentos da vida e, portanto, as próprias bases da legitimidade das decisões autônomas do capital, e que os próprios Estados-nação atuam simultaneamente de maneira legítima e ilegítima. O célebre sociólogo tornou-se, com um ganho progressivo de densidade em suas análises, um observador arguto dos enredos encenados pelos diversos atores sociais em torno dos perigos da segunda modernidade. Entretanto, na sua obra mais madura, o estudo do modo como o risco e a vulnerabilidade são construídos ainda constitui uma função do modo como estes riscos e vulnerabilidades são encenados. Em outras palavras, para utilizar a terminologia de Acosta, Beck enfrenta diretamente o problema da construção social de riscos; porém, a referida produção das situações sociais de vulnerabilidade desperta interesse apenas em razão do fato de que o risco é encenado socialmente de tal ou tal modo, no bojo da reflexividade complexa das relações entre diferentes atores, na sociedade mundial de risco. $\mathrm{O}$ que se perde nessa abordagem é o estudo dos processos constitutivos dos antagonismos sociais em si mesmo considerados, independente dos processos sociais de definição de riscos e vulnerabilidades. De que natureza seriam esses processos, à parte seus modos de representação? Qual o lugar do político em face dessa lacuna?

Sem prejuízo de outras abordagens, falta em Beck a conceptualização do modo de produção capitalista, particularmente em um contexto de hegemonia do capital financeiro. Nesse sentido, para Žižek, a teoria da sociedade de risco, ao passo que concebe as incertezas e os riscos fabricados como característica universal da vida

\footnotetext{
${ }^{71}$ Id., p. 307.

${ }^{72}$ Id., p. 310-311

${ }^{73}$ BECK, Ulrich. Potere e Contrapotere nell'etá globale. Traduzione di Carlo Sandrelli. Roma: Laterza, 2010 [2002]. 455 p., p. 311 312 . 
contemporânea, acaba por ocultar as raízes socioeconômicas destes riscos ${ }^{74}$. É certo que Beck evoca acertadamente a necessidade de uma repolitização radical da sociedade, inclusive mediante o enfrentamento do problema do mercado global despolitizado, que precisa ser civilizado. Entretanto, argumenta-se com Žižek, os teóricos da sociedade de risco "omitem pôr em questão os próprios fundamentos da lógica anônima das relações do mercado e do capitalismo global"75. Uma vez aceitos este fundamentos de maneira acrítica, o "mercado" aparece como Real neutro fora do alcance de qualquer processo de politização, ainda que se reconheça e que se pleiteie a necessidade de civilizá-lo:

Enquanto aceitarmos esta despolitização fundamental da esfera económica, todas as discussões sobre a cidadania activa, o debate público susceptível de conduzir a decisões colectivas responsáveis, etc., continuarão limitados a problemas 'culturais', ligados a diferenças religiosas, sexuais, étnica, de modos de vida, sem interferirem efectivamente no nível em que são tomadas as decisões a longo prazo que nos afectam a todos. Em suma, a única maneira eficaz de produzir uma sociedade em que as decisões a longo prazo comportando riscos seguiriam um debate público envolvendo todos os actores implicados consiste numa espécie de limitação radical da liberdade do Capital e na subordinação do processo de produção ao controlo social na radical repolitização da economia. ${ }^{76}$

Observa-se $^{77}$ que a denúncia dos antagonismos resultantes da economia globalizada, na ótica de Beck, acaba por alimentar a ira popular, na medida em que serão frustradas as expectativas de igualdade criadas, o que constitui, precisamente, uma das principais causas dos movimentos sociais globais. No entender de Beck ${ }^{78}$ a teoria sociológica deve contribuir para a reinvenção do político, mediante a superação metodológica da equação sociedade/Estado-Nação, perscrutando os diversos tipos de situações de risco, o modo pelo qual as vulnerabilidades são distribuídas e a conformação das dinâmicas de conflito na sociedade mundial do risco. Entretanto, a "reorganização do poder e da responsabilidade" pretendidos por Beck não podem lograr êxito sem o enfrentamento de problemas socioeconômicos fundamentais, que dizem respeito à compreensão das necessidades estruturais da economia capitalista na era do capital financeiro, e ao modo pelo qual este se relaciona com as instituições político-jurídicas, com as dinâmicas do espaço urbano, com o domínio da ética, com a cultura e com a esfera doméstica.

\footnotetext{
${ }^{74}$ ŽIŽEK, Slavoj. O Sujeito incômodo: o centro ausente da ontologia política. Tradução Carlos Correia Monteiro de Oliveira. Lisboa: Relógio D'Água, 2009. 400 p.,p. 339.

${ }^{75}$ Id., p. 349.

76 ŽIŽEK, Slavoj. O Sujeito incômodo: o centro ausente da ontologia política. Tradução Carlos Correia Monteiro de Oliveira. Lisboa: Relógio D'Água, 2009. 400 p.,p. 351.

77 BECK, Ülrich. La revuelta de la desigualdad: El enriquecimiento rápido convirtió a muchos en dependientes de la droga del dinero prestado. Ahora los ricos poseen un poco menos, pero a los pobres no les alcanza para vivir. La situación es (pre)revolucionaria. El País. Madri. 04 maio 2009. Disponível em: <http://elpais.com/diario/ 2009/05/04/opinion/1241388011_850215.html>. Acesso em: 15 mar. 2015

${ }^{78}$ Id., p. 163.
} 
Uma reivenção do político pressuporia avançar na compreensão daquilo que, para além das novas demandas identitárias e particularistas, permanece o mesmo na pós-política contemporânea, que é a "inexorável lógica do capital", sempre e cada vez mais despolitizada ${ }^{79}$, à parte dos seus processos de mediação reflexiva. Para Žižek, é sintomático o fato de que o impacto pós-político autenticamente libertador das lutas sociais naqueles domínios dantes considerados apolíticos e hoje entendidos como intrinsecamente políticos (v. g., do ecologismo, do feminismo, de identidade étnica, de orientação sexual, etc.), acompanhe uma progressiva despolitização da esfera econômica. Nesta esteira, seria pertinente a defesa de um "regresso ao primado da economia"; porém, não em detrimento das questões particularistas e identitárias levantadas pelas formas pós-modernas de politização, e sim justamente para que estes e outros direitos possam ser realizados de maneira mais efetiva ${ }^{80}$. Afinal, nesta ótica, o imperativo econômico sempre acaba por refletir nas diversas formas de denegação de direitos.

\section{A DIMENSÃO POLÍTICA DOS MOVIMENTOS SOCIAIS URBANOS E A TEMÁTICA DA EMANCIPAÇÃO HUMANA}

Ao tratar das revoltas da desigualdade globais, Beck ${ }^{81}$ faz a crítica da atuação dos Estados-nação, que praticam um socialismo de Estado só para ricos, com seus socorros bilionários para o setor financeiro e com o recrudescimento da pressão sobre os pobres, o que seria o mesmo que "apagar o fogo com fogo", na medida em que se produz mais frustração e se potencializam as mazelas sociais. Tratar-se-ia, no seu entender, de uma situação pré-revolucionária que, não obstante, carece de um sujeito revolucionário, tendo em vista sua abrangência global, a diversidade dos atores e das pautas envolvidas. A alegada ausência de sujeitos revolucionários na sociedade de risco permite uma interessante articulação com a forma como Beck aborda a questão política (ou, mais precisamente, com a concepção de política implícita em seus escritos).

Tal como propõem Dias e Neves no texto introdutório da coletânea A política dos muitos ${ }^{82}$, entende-se que as revoltas populares ocorridas neste início de século XXI, tão intensas e peculiares, requerem o esforço transdisciplinar de (re)pensar a ação política de maneira plural, na contracorrente de uma tradição liberal que toma o indivíduo como "princípio e fim do viver comum" ${ }^{3}$. Apesar da crise da teorização da política como questão coletiva, os eventos recentes de protestos, somados à crise de legitimidade dos sistemas políticos e

\footnotetext{
${ }^{79}$ ŽIŽEK, Slavoj. O Sujeito incômodo: o centro ausente da ontologia política. Tradução Carlos Correia Monteiro de Oliveira. Lisboa: Relógio D'Água, 2009. 400 p., p. 351-352.

${ }^{80}$ Id., p. 353-354.

${ }^{81}$ BECK, Ülrich. La revuelta de la desigualdad: El enriquecimiento rápido convirtió a muchos en dependientes de la droga del dinero prestado. Ahora los ricos poseen un poco menos, pero a los pobres no les alcanza para vivir. La situación es (pre)revolucionaria. El País. Madri. 04 maio 2009. Disponível em: <http://elpais.com/diario/ 2009/05/04/opinion/1241388011_850215.html>. Acesso em: 15 mar. 2015

${ }^{82}$ DIAS, Bruno Peixa; NEVES, José. Introdução. In: DIAS, Bruno Peixa; NEVES, José (coord.). A política dos muitos: povo, classes e multidão. Lisboa: Tinta da China, jun. 2010, 446 p.

${ }^{83}$ Id., p. 9.
} 
econômico, pedem por uma reflexão crítica renovada em torno da (tentativa de) designação de sujeitos plurais da ação política (tais como povo, multidão, classes ou massas). A consolidação do povo como sujeito político coletivo desde finais do século XVIII responde a inequívocas conquistas históricas, já fartamente trabalhadas, seja no viés crítico ou apologético. Sabe-se que o discurso geralmente aceito apresenta o povo como instância originária e destinatária do poder soberano, em uma concepção democrática, popular e nacional, por oposição a todas as formas antidemocráticas precedentes ${ }^{84}$. Este é, inclusive o fundamento do poder soberano no texto constitucional dos países tidos como democráticos. Na narrativa do constitucionalismo e da soberania popular, cabe ainda (e cada vez mais) ao povo defender a democracia daqueles que pretendam negá-la. Paradoxalmente, justifica-se o princípio da verticalidade e aquele que é, na prática, o governo de poucos (na forma de uma oligarquia ou plutocracia), mediante o culto da figura das elites, sobretudo em razão de uma estereotípica desigualdade das inteligências e das capacidades - a qual, não por acaso, reflete no modo como o argumento leigo e o argumento perito são tematizados nas decisões públicas.

A teoria da sociedade mundial do risco é perspicaz ao articular o tema do cosmopolitismo metodológico, oferecendo importantes ferramentas para a superação da perspectiva nacionalista no agir político e na reflexão acadêmica. Da mesma forma, são inegáveis as contribuições de Beck ao problematizar as falácias do conhecimento especializado e as relações entre a política e a ciência (e o direito) na conceptualização e gestão dos riscos civilizatórios. Estes desenvolvimentos teóricos representam uma espécie de ponto alto na trajetória do risco enquanto objeto de estudo comum às ciências naturais e sociais, conforme referido no início deste ensaio. Entretanto, ao contrário daqueles pontos em que peca pela falta base empírica (quando defende, por exemplo, o postulado da superação da sociedade de classes), a teoria da sociedade mundial do risco parece, por vezes, ressentir-se da falta de ferramentas conceituais no âmbito da ciência/teoria política. Este argumento é particularmente claro quando se trata de articular os temas da ação política e do dissenso.

Do ponto de vista das estruturas políticas, o ressurgimento do dissenso neste início de século é bastante compreensível. Conjugados, diversos processos reduzem a democracia liberal a uma pálida sombra do que foi no passado, processo que Wendy Brown chama desdemocratização ${ }^{85}$. Para esta cientista política, o poder das grandes empresas e sua ingerência sobre os agentes políticos e sobre os meios de comunicação redunda em algo muito próximo da possibilidade de escolha (compra) da assim chamada "opinião pública”. Ademais, o processo eleitoral vem sendo mundialmente reduzido a um "circo" administrado pelo marketing e pelo management, vendidas as questões de interesse comum como bens de consumo. A expressão democracia de mercado traduz a progressiva erosão dos fundamentos da própria democracia liberal - tais como o constitucionalismo, a liberdade civil e

\footnotetext{
${ }^{84}$ DIAS, Bruno Peixa; NEVES, José. Introdução. In: DIAS, Bruno Peixa; NEVES, José (coord.). A política dos muitos: povo, classes e multidão. Lisboa: Tinta da China, jun. 2010, p. 9-11.

${ }^{85}$ BROWN, Wendy. Oggi Siamo tutti democratici... In: AGAMBEM, Giorgio [et. al.]. In che stato é la democrazia? Traduzioni di Andrea Aureli e Carlo Milani. Roma: Nottetempo, 2010 [2009], p.71-95.
}

vol.08, n. 03, Rio de Janeiro, 2015.pp. 1913-1948 
autonomia política - em face de critérios como custo/benefício e eficiência de mercado, em um cenário neoliberal pós meados dos anos 1970. É licito falar em uma "governança dos tribunais", processo de expansão exagerada do poder jurisdicional, mascarada pela expertise técnica, no sentido da usurpação da prerrogativa legislativa da política democrática. Há que se mencionar, por fim, a perda de significado político da democracia, decorrente da erosão da soberania do Estado nacional em face da globalização, fenômeno que é desacompanhado da delimitação de uma base diversa para o exercício da democracia ${ }^{86}$.

Assim, para equacionar os nomes do sujeito político coletivo (e a própria recorrência histórica do dissenso deixa evidente) é preciso rejeitar simultaneamente ${ }^{87}$ : (i) a fixação do sujeito da política em uma essência individual, que secundariza a identidade coletiva em nome do interesse próprio; e (ii) a suposição de uma identidade coletiva una e determinada, capaz de anular, de uma vez por todas, as subjetividades individuais em prol de um todo harmônico. Por outras palavras, a subjetivação política deve ser pensada na relação entre individual e coletivo e não naturalizada lá ou cá. O deslocamento necessário não ocorre de um polo a outro do problema, ou seja, de uma essência individual em direção a uma essência coletiva, e sim da resposta para a pergunta, ou seja, da busca de uma paradoxal subjetividade naturalizada para a busca das condições de emergência da uma subjetividade política. Nessa (re)volta autocrítica para a pergunta, o pensador da política, em todas as áreas afins do conhecimento, depara-se com a difícil dialética entre o individual e o coletivo; entre a política orgânica e a política emancipatória; entre a comunidade policial e a comunidade política.

Beck deixa bem claro que a teoria da sociedade mundial do risco não assume a existência de um sujeito histórico capaz de levar a efeito um projeto de cosmopolitismo (a world historical subject of consmopolitanization), nem pretende determinar a direção ou os resultados da mudança global ${ }^{88}$. Contudo, os teóricos da sociedade de risco, para citar a crítica de Žižek ${ }^{89}$, subestimam o impacto que a lógica social por eles mesmos descrita desempenha sobre o estatuto fundamental da subjetividade. A universalização da reflexividade, tal como descrita por Beck e Giddens, condiz com o desaparecimento da natureza e da tradição, tal como entendidas até então. Paradoxalmente, entende o filósofo esloveno, o sujeito das "segundas luzes", capaz de decidir livremente sobre seu destino com uma nova liberdade, politizando democraticamente os processos decisórios sobre riscos civilizacionais, apresenta o mesmo modo de subjetivação fundamental do sujeito moderno; ou seja,

\footnotetext{
${ }^{86}$ Id., p.74-79.

${ }^{87}$ DIAS, Bruno Peixa; NEVES, José. Introdução. In: DIAS, Bruno Peixa; NEVES, José (coord.). A política dos muitos: povo, classes e multidão. Lisboa: Tinta da China, jun. 2010, p. 12.

${ }^{88}$ BECK, Ulrich. World at risk. Translated by Ciaran Cronin. Cambridge: Polity Press, 2009, p. 186.

${ }^{89}$ ŽIŽEK, Slavoj. O Sujeito incômodo: o centro ausente da ontologia política. Tradução Carlos Correia Monteiro de Oliveira. Lisboa: Relógio D'Água, 2009. 400 p.,p. 340.
} 
"continua a ser o sujeito moderno, capaz de raciocínio e reflexão livre, de escolha e decisão quanto aos seus conjuntos normativos" ${ }^{\prime 90}$.

Lógica de Beck é essencialista com relação ao indivíduo muito embora, paradoxalmente, seja o pensador do risco e, portanto, do imprevisto, daquilo que escapa à lógica da previsão. Essa confiança de Beck na subjetividade iluminista é patente em seus escritos, apesar das ponderações recorrentes sobre a incapacidade de prever o futuro, o que permite sustentar, em face do tema da individuação, que o sujeito individual é o ator fundamental da política na sociedade mundial do risco. Diversamente - e tomando de empréstimo, para fins de síntese, o pressuposto teórico da coletânea A política dos muitos -, argumenta-se que a fixação de um sujeito coletivo da política é impossível "não porque esse sujeito seja individual, muito pelo contrário, mas justamente porque não é identificável", porque qualquer tentativa de o encerrar em um conceito fixo, incorre no erro de cristalizar aquilo que escapa a toda a lógica de previsão ${ }^{91}$. Este parece o postulado essencial para trabalhar a questão da emergência dos movimentos sociais urbanos e seu significado político.

A abordagem do dissenso em Rancière ${ }^{92}$ é especialmente prolífica para a concepção do evento político sob a rubrica do dissenso, e oferece um formidável contraponto crítico à abordagem da reinvenção do político em Beck. Para Rancière ${ }^{93}$, a política é precisamente aquilo que resiste a toda operação de estabilização, porquanto excede a lógica do funcionamento do social e do econômico: a subjetivação política em geral ocorre quando um nome de sujeito e uma forma de predicação produzem uma esfera de experiência inédita, que não tem lugar nas regras de inclusão e modos de visibilidade existentes; e portanto, declara como atores daquilo que é comum aqueles que antes eram apenas pessoas privadas, elevando à discussão pública o que antes era próprio apenas da esfera doméstica. Enquanto o consenso é a tentativa de "reconduzir o comum a regras de inclusão simples", a comunidade que se abre em experiências de subjetivação política é o espaço do dissenso. A afirmação do dissenso revela a exclusão de muitos daquele espaço comum original e presumivelmente harmônico, e pretende integrar nele aquilo que dele não faz parte:

\footnotetext{
${ }^{90}$ Id., p. 340.

${ }^{91}$ DIAS, Bruno Peixa; NEVES, José. Introdução. In: DIAS, Bruno Peixa; NEVES, José (coord.). A política dos muitos: povo, classes e multidão. Lisboa: Tinta da China, jun. 2010, p. 22.

92 Dentre outras obras, Cf. RANCIÈRE, Jacques. O desentendimento: política e filosofia. tradução de Ângela Leite Lopes. São Paulo: 34, 1996, 144 p;. RANCIÈRE, Jacques. A partilha do sensível: estética e política. tradução de Mônica Costa Netto. São Paulo: 34, 2005. 72 p; RANCIÈRE, Jacques. Staging the people: the proletarian and his double. Translated By David Fernback. London Verso, 2011; RANCIÈRE, Jacques. The intellectual and his people: staging the people vol. 2. Translated By David Fernback. London Verso, 2012; RANCIĖRE, Jacques. O mestre ignorante: cinco lições sobre a emancipação intelectual. Tradução Lillian do Valle. Autêntica: Belo Horizonte, 2002, 143 p.; RANCIÈRE, Jacques. O espectador emancipado. Tradução Ivon Benedetti. São Paulo: Martins Fontes, 2012, p. 128 p. RANCIÈRE, Jacques. O ódio à democracia. Tradução Marina Echalar. São Paulo: Boitempo, 2014, 125 p.

93 RANCIÈRE, Jacques. A comunidade como dissentimento: Jacques Rancière (com François Noudelman). In: DIAS, Bruno Peixa; NEVES, José (coord.). A política dos muitos: povo, classes e multidão. Lisboa: Tinta da China, jun. 2010. p. 425-436.
} vol.08, no. 03, Rio de Janeiro, 2015.pp. 1913-1948 
Aquilo que recuso é fundar a comunidade política numa propriedade antropológica ou numa disposição ontológica primeira. Quer se funde a política numa sociabilidade natural ou na necessidade de lutar contra uma insociabilidade natural, quer seja fundada no fulgor do agir dos aristoi ou na exposição comum do dasein, quer se dilate o conteúdo das propriedades partilhadas ou se entenda reduzi-lo ao "em" do "em-comum", permanecemos sempre nesse dispositivo que pensa a política em termos de comunidade e a comunidade a partir de uma propriedade ou disposição original ao comum. Para mim, a política é sempre segunda. O problema de saber se é necessário pormo-nos em comunidade e porque é que estamos nela é sempre resolvido de antemão. Já existe sempre comunidade entre os corpos: a que se liga ao corpo soberano, à filiação humana e divina, ao lugar no sistema das distribuições econômicas e sociais, etc. A política vem depois como invenção de uma forma de comunidade que suspende a evidência das outras, instituindo relações inéditas entre as significações, entre as significações e os corpos, entre os corpos e seus modos de identificação, lugares e destinos. Pratica-se repondo em questão as adesões comunitárias existentes e instituindo essas relações novas, essas "comunidades" entre termos que põem em comum [...]. O intervalo político tem mais a ver com o salto da metáfora do que com qualquer forma de comunhão $0^{94}$

A questão do sujeito político coletivo, segundo o diagnóstico de Dias e Neves, tem suscitado dois tipos de respostas entre aqueles que recusam uma concepção individualista da política. $\mathrm{O}$ primeiro passa pelo abandono de quaisquer tentativas de encontrar um sujeito universal da política, procurando-se acima de tudo a valorização identitária e particularista dos excluídos, tais como as reivindicações de minorias sexuais, raciais e culturais, bem como questões de gênero etc. Um segundo tipo de resposta, por oposição às políticas identitárias, reside no esforço de atualização do universalismo, sobretudo por meio do princípio da luta de classes, "seja por uma política de inclusão dos sujeitos anteriormente excluídos da luta de classes, seja pela procura teoria e prática de novas lógicas de subjectivação política" ${ }^{\text {"95 }}$. Sem dúvida, Rancière integra corrente da teoria crítica que sustenta esta retomada do universalismo em política, relegado a segundo plano dentro e fora do meio acadêmico.

Žižek ${ }^{96}$, fazendo eco a Rancière, explica que a política surgiu na Grécia Antiga quando os membros do demos não apenas exigiram ser ouvidos e reconhecidas e reconhecidos como fazendo parte da esfera pública. Mais do que isso, os membros do demos apresentaram-se enquanto excluídos que, justamente por não ocupar qualquer posição justa no interior do edifício social, consideravam-se os porta-vozes da sociedade no seu conjunto, em nome de uma autêntica universalidade contra os interesses particulares daqueles que detinham o poder:

Em resumo, o conflito político designa a tensão entre o corpo social estruturado, dentro do qual cada parte ocupa o seu lugar, e a afirmação de que "há uma parte dos sem-parte" [Rancière] que vem abalar essa ordem em razão do princípio de universalidade vazio, daquilo a que Balibar chama a

\footnotetext{
${ }^{94}$ Id., p. 426-427.

${ }^{95}$ DIAS, Bruno Peixa; NEVES, José. Introdução. In: DIAS, Bruno Peixa; NEVES, José (coord.). A política dos muitos: povo, classes e multidão. Lisboa: Tinta da China, jun. 2010, p. 19-20.

${ }^{96}$ ŽIŽEK, Slavoj. Elogio da intolerância. Tradução Miguel Serras Pereira. Lisboa: Relógio D'Água, 2006, 148 p., p. 33-35.
} vol.08, no. 03, Rio de Janeiro, 2015.pp. 1913-1948 
igualiberdade, a igualdade de princípio de todos os homens enquanto seres dotados de palavra. $\mathrm{O}$ próprio da política induz sempre, portanto, uma espécie de curto-circuito entre o universal e o particular: o paradoxo de um singular universal, de um singular que aparece como o substituto do universal, repondo em questão a ordem funcional "natural" das relações no interior do corpo social. Esta identificação dos sem-parte com o Todo, da parte da sociedade que é desprovida de lugar verdadeiramente justo dentro dela (ou à qual repugna aceitar o lugar de segunda categoria que dentro dela lhe é concedido) com o universal é o gesto elementar da politização, detectável em todos os grandes acontecimentos democráticos, da Revolução francesa (em cujo decorrer o terceiro estado se proclamou idêntico à Nação enquanto tal, contra a aristocracia e o clero) ao desaparecimento do ex-socialismo europeu (em cuja ocasião os fóruns dissidentes se instituíram como representativos da sociedade inteira contra a nomenklatura do partido). Nesta acepção precisa, política e democracia são sinónimas: o desígnio fundamental de uma política antidemocrática é e foi sempre, e por definição, a despolitização, quer dizer, a reclamação incondicional de que "as coisas regressem ao normal" e de que cada indivíduo retome seu posto... ${ }^{97}$.

Neste sentido preciso, portanto, a política não traduz a harmonia do todo social, seja qual foi o princípio garantidor dessa harmonia. Da mesma forma, a política também não reside na revolta; posto que, nesse sentido, é apenas reforçado o ponto de vista da ordem estabelecida, que vê um gigantesco concerto entrecortado por ruídos de instrumentos dissonantes (a questão, de todo modo, é retomar a mesma música, e não outra diversa). A condição da política não é realizada “simplesmente porque os pobres se opõem aos ricos”, senão na emergência da "pressão exorbitante do demos a ser o todo da comunidade"; ou seja,

Quando a ordem natural da dominação é interrompida pela instituição de uma parcela dos sem-parcela. Essa instituição é o todo da política enquanto forma específica de vínculo. Ela define o comum da comunidade como comunidade política, quer dizer, dividida, baseada num dano que escapa à aritmética das trocas e reparações. Fora dessa instituição, não há política. Há apenas ordem da dominação ou desordem da revolta ${ }^{98}$.

Assim, para além do propósito habermasiano de um debate racional entre interesses múltiplos, o que caracteriza a política não seriam as reivindicações particulares, ainda que legítimas, como aquela por melhores condições de trabalho - ou, nas Jornadas de Junho, o transporte gratuito ou de custo razoável e de qualidade, o questionamento do papel das polícias e do Ministério Público em face da segurança pública, o direcionamento dos gastos com eventos esportivos para questões sociais, o preconceito contra homossexuais, e assim por diante. O evento político seria discernível na afirmação sistemática do dissenso e, daí, na reivindicação universalista em prol de um mundo mais igualitário - clamor que pressupõe a ruptura, no sentido de que seja conferido um lugar justo na ordem social àqueles que dela não fazem parte. Trata-se da afirmação de que o todo social não é todo,

\footnotetext{
${ }^{97}$ Id., p. 34-35

${ }^{98}$ RANCIÈRE, Jacques. O desentendimento: política e filosofia. tradução de Ângela Leite Lopes. São Paulo: 34, 1996, p. 26-27. vol.08, nº. 03, Rio de Janeiro, 2015. pp. 1913-1948
} 
pois há algo ou alguém que extrapola a presunção (e a possibilidade mesma) de harmonia dentro das coordenadas geralmente aceites.

Situada na articulação entre os planos da política e da estética, a abordagem de Rancière constitui contraponto privilegiado a fim de se argumentar que a teoria da sociedade de risco não fornece um instrumental teórico apropriado para pensar o político em um contexto de dissenso. Nesta linha de raciocínio, é possível afirmar que a sociologia do risco de Beck assume, ainda que com propósito crítico, um ponto de vista interno do edifício social, sob a mirada de um horizonte harmônico. Desse ângulo, os eventos de Jornadas de Junho, Occupy e Indignados podem ser compreendidos em seus efeitos discursivos, seus limites programáticos, suas repercussões "políticas"; contudo, serão sempre e ainda revoltas, manifestações de desordem, uma forma de ruído. Por este motivo, reputa-se que o direcionamento conferido por Beck ao tema da reinvenção do político, muito embora coerente com a noção de modernidade reflexiva, resulta em flagrante lacuna a propósito da emergência dos movimentos sociais urbanos e sua teorização.

\section{CONCLUSÕES}

O presente texto permitiu debater alguns dos conceitos e noções essenciais da teoria da sociedade (mundial) de risco de Ülrich Beck, de modo a refletir sobre o seu potencial interpretativo, em face do tema da emergência das recentes manifestações públicas de caráter urbano e radical, no Brasil e no mundo. Observa Harvey ${ }^{99}$ que as desigualdades socioespaciais contemporâneas emergem sobretudo no espaço urbano, nele proliferando-se e intensificando-se de maneira patológica - o que resulta, mais cedo ou mais tarde, em tensão civil. As Jornadas de Junho, particularmente, podem ser entendidas no contexto da luta pelo direito à cidade, noção que, muito mais do que um simples modismo intelectual, "surge basicamente das ruas, dos bairros, como um grito de socorro e amparo de pessoas oprimidas em tempos de desespero" ${ }^{100}$. Sem entrar no mérito da questão, pode-se afirmar que a intersecção entre o tema da política emancipatória e o problema urbano é absolutamente atual, de maneira que constitui desafio intelectual de primeira ordem compreender as fraturas sociais de que as manifestações recentes resultam e problematizar seu significado político em um médio e longo prazo.

A reflexão sobre o lugar da teoria de Beck em face das abordagens sobre o risco nas ciências sociais é bastante reveladora dos pontos fortes e das lacunas da obra deste proeminente sociólogo, enquanto matriz de análise dos problemas urbanos, em geral, e da emergência das Jornadas de Junho, em particular. O resgate de algumas tipologias sobre o estudo do risco permite identificar a filiação de Beck à matriz dita culturalista, cujo enfoque recai sobre as percepções culturais (de determinadas sociedades, grupos, indivíduos e instituições) acerca

\footnotetext{
${ }^{99}$ HARVEY, David. A liberdade da cidade. In: MARICATO, Ermínia. [et al.] Cidades rebeldes: Passe Livre e as manifestações que tomaram as ruas do Brasil. 1 ed. São Paulo: Boitempo: Carta Maior, 2013.p. 25-34., p. 29.

${ }^{100}$ HARVEY, David. Cidades Rebeldes: do direito à cidade à revolução urbana. São Paulo: Martins Fontes, 2014, p. 15-16 vol.08, nº. 03, Rio de Janeiro, 2015.pp. 1913-1948 
dos perigos da segunda modernidade. Argumenta-se que, apesar da abertura de importantes perspectivas nos escritos mais recentes, a teoria da sociedade (mundial) de risco não responde às demandas das ciências sociais por um enfoque integrador ou multidimensional nos estudos sobre o risco, antes subordinando a interpretação do mundo social ao problema das relações de definição em torno dos riscos. Assim, de um lado, tal abordagem resulta em um instrumental privilegiado para compreensão dos choques culturais e institucionais de percepções contraditórias acerca das incertezas contemporâneas, permitindo investigar como os riscos são assumidos, negados, distribuídos na disputa entre os diversos atores sociais. Por outro lado, é possível afirmar que a teoria da sociedade (mundial) de risco carece de análises mais consistentes acerca da forma como os riscos são objetivamente produzidos, ou seja, sobre os processos que estão na origem da proliferação dos perigos civilizacionais contemporâneos, independentemente do problema de sua mediação reflexiva. Da mesma forma, sustenta-se que a teoria negligencia a questão das raízes daqueles problemas sociais que sequer podem ser caracterizados como problemas de risco. Por fim, sustenta-se que essa sociologia do risco, que contém uma teoria política ao menos implícita, contém outra importante lacuna no que toca à compreensão dos movimentos sociais urbanos, que é justamente a forma como concebe o evento político.

Em última instância, o problema dos movimentos sociais urbanos, sob a rubrica da modernidade reflexiva, redundará na tematização sobre o modo como os riscos e as vulnerabilidades sociais serão socialmente encenadas. Nesse sentido, a obra de Beck contém noções muito importantes para análise dos movimentos sociais urbanos. Como exemplo, vale citar tópico da irresponsabilidade organizada, no contexto da reflexão sobre o fatalismo industrial, a qual leva o autor a discutir os modos pelos quais os riscos são maquiados, denegados, aceitos como parte integrante da normalidade cotidiana ou institucional. Por outro lado, a obsessão do autor pelo caráter reflexivo do risco o fará minimizar (ou denegar) toda uma dimensão relativa aos processos conformadores dos problemas sociais. Essa característica é completamente coerente com a pretensa superação da sociedade de classes, inseparável do advento de uma sociedade de risco nos moldes propostos.

Em se tratando, especificamente, de riscos ecológicos, sanitários, econômicos, urbanísticos, é fundamental compreender os conflitos em torno de sua encenação pelos mais diversos atores sociais, inclusive pelas instituições jurídico-políticas, bem como os paradoxos que estas relações de definição comportam. Não menos importante, porém, é compreender de quais doenças sociais a imensa proliferação de riscos contemporânea constitui sintoma. Por outro lado, os problemas urbanos que poderiam explicar o advento de atos contestatórios de amplo espectro e de grande radicalidade nem sempre remetem a situações de risco. Trata-se, muitas vezes, de problemas amplamente conhecidos, mensuráveis em suas consequências, atuais e crônicos situações que não comportam qualquer elemento de incerteza em sua caracterização, que fogem à lógica da possibilidade do desastre futuro, sobre o qual existe ou poderia existir um conflito de percepções. A grande 
dificuldade, nessas situações, não é mapear os processos sociais de definição e distribuição de riscos, em suas ambiguidades e em sua complexidade, mas compreender as raízes (socioeconômicas e outras) das fraturas civilizacionais, como elas são possíveis, porque são de certo modo necessárias, porque em dado momento se tornam insuportáveis para grandes contingentes, ainda que largamente conhecidos seus efeitos.

Assim, a teoria da sociedade (mundial) de risco será fundamental, por exemplo, para que se investigue aquilo que se diz a respeito da desigualdade social, ou dos efeitos da economia globalizada sobre a vida urbana. Permitirá refletir sobre como isso que se diz (no plano institucional, acadêmico, jornalístico) resulta em decisões tendentes a mascarar ou a perpetuar perigos - perigos estes que são ou não percebidos, falados e representados, conforme o caso. Fornecerá, ademais, importantes considerações sobre qual perspectiva metodológica será mais adequada à compreensão dos paradoxos reflexivos que cercam os processos sociais de definição e distribuição de riscos e vulnerabilidades, sobretudo os processos decisórios de ordem político-jurídica que impactam sobre as mazelas urbanas. De outra parte, não oferecerá um instrumental teórico para compreensão dos processos constitutivos destes problemas, das suas raízes multicausais. Consequentemente, não fornecerá um aparato consistente para a reflexão acerca do significado político da emergência dos movimentos sociais recentes, no Brasil e no mundo.

Muito embora tenha criado, em razão do seu próprio sucesso, diversos perigos para a própria vida humana na Terra, a sociedade mundial do risco guarda em si, no entender de Beck, o potencial para reinventar-se de maneira reflexiva. Entretanto não resta claro por que razão a mesma subjetividade que está na base de um progresso industrial tendencialmente catastrófico poderia constituir o fundamento de uma nova reinvenção do político sob bases iluministas, com a politização democrática dos processos decisórios segundo uma perspectiva de cosmopolitismo metodológico. Pode-se identificar, nessa petição por uma reorganização do poder e da responsabilidade, antes um sentido de continuidade do que um sentido de ruptura com os fundamentos políticos, econômicos e ideológicos da ordem global estabelecida. Não que não se trate, com Beck, de um movimento de "reinvenção"; contudo, a reinvenção proposta carrega um sentido ambíguo de continuidade acerca do estatuto da subjetividade, bem como de continuidade no plano socioeconômico, em que as decisões mais importantes permanecem na esfera daquilo que não se pode decidir. Argumenta-se, por conseguinte, que é possível localizar a reinvenção do político proposta no contexto teorético da sociedade mundial do risco nos limites daquilo que Rancière ${ }^{101}$ designa comunidade policial: ou seja, ainda que assumindo um viés crítico, presa a um projeto de consenso, de reafirmação da qualidade tendencialmente harmônica do corpo social, e não no âmbito próprio da comunidade política, que põe em causa a ordem estabelecida a partir da emergência do dissenso.

${ }^{101}$ RANCIÈRE, Jacques. A comunidade como dissentimento: Jacques Rancière (com François Noudelman). In: DIAS, Bruno Peixa; NEVES, José (coord.). A política dos muitos: povo, classes e multidão. Lisboa: Tinta da China, jun. 2010. p. 427-428. vol.08, nº. 03, Rio de Janeiro, 2015.pp. 1913-1948 
Aplicada às Jornadas de Junho, a reflexão de Rancière permite compreender que os movimentos sociais urbanos contemporâneos não devem ser pensados apenas do ponto de vista de suas reivindicações específicas, muito embora tratem-se de reivindicações legítimas -como no que diz respeito ao movimento "passe-livre", que foi uma espécie de estopim de uma série de protestos com vários conteúdos específicos e, por momentos, contraditórios ou sem conteúdo discernível. Estas manifestações, que persistem ao longo do tempo, e que assumiram enormes dimensões, também refletem as fraturas do corpo social, na medida em que afirmam um inolvidável dissenso perante o consenso sustentado pela ordem político-econômica vigente. Abstraídas suas reivindicações particulares (que, por vezes, são idealizadas, ou até contraditórias), os movimentos sociais urbanos de protesto, portadores de um conteúdo radical, podem ser compreendidos como manifestações de desidenticação ou dissenso - e, portanto, como reivindicações por um lugar no corpo social, que partem de atores que não encontram ou não compreendem o seu lugar nesta ordem, supostamente legítima e tendencialmente harmônica.

Ao cotejar a compreensão do político em Beck e em Rancière, não se pretende oferecer uma interpretação definitiva sobre as Jornadas de Junho, ou sobre os movimentos sociais urbanos de protesto como um todo. Entretanto, o procedimento serve, por efeito de contraste, para indicar a limitação oferecida pela teoria da sociedade mundial de risco neste particular. Parte-se do pressuposto, convém esclarecer, de que a teorização do político como consenso ou como dissenso não são necessariamente excludentes, ao menos do ponto de vista acadêmico; ou seja, são iniciativas válidas a priori. Entretanto, os eventos ora considerados são, sem sombra de dúvida, portadores de desidentificação, de modo que é fundamental interpretá-los sobre o pano de fundo da teorização da política emancipatória. É precisamente o caso concreto, portanto, que demanda a investigação pautada na concepção do espaço político como manifestação de dissenso, e não uma opção de caráter abstrato ou de fundo dogmático.

Nesse sentido específico, pela ótica da teoria crítica voltada à compreensão da política como evento, a posição de Beck, a despeito da inolvidável contribuição que representa sua obra, despolitiza os movimentos sociais urbanos, uma vez que não tem por objetivo vislumbrar os antagonismos sociais subjacentes, suas raízes socioeconômicas, seus processos constitutivos. Nesse sentido, seria conveniente interpretar os eventos de protesto portadores de um discurso radical como manifestações políticas de dissenso, independente da análise dos conteúdos específicos portados pelos manifestantes e da forma como são integrados nos processos de definição de pautas políticas. Tão importante quanto pensar o que fazer (e compreender o que se fará) com os conteúdos das reivindicações, é compreender que os manifestantes em si mesmos constituem um reflexo do malestar resultante da falta de perspectivas no interior da ordem social estabelecida. Longe de anunciar o fim das subjetividades políticas emancipatórias, as controversas manifestações sociais urbanas deste início de milênio 
podem ser investigadas enquanto sintomas ${ }^{102}$ de um mundo social cindido, cujas patologias essenciais não são adequadamente enfrentadas e cujas vozes dissonantes querem deixar de ser apenas ruído.

\title{
THE THEORY OF RISK SOCIETY AS A TOOL FOR UNDERSTANDING THE EMERGENCE OF URBAN SOCIAL MOVEMENTS IN BRAZIL: A CRITICAL COUNTERPOINT
}

\begin{abstract}
This text deals with the theory of world risk society, developed by Ülrich Beck, as a tool for understanding Jornadas de Junho movement in Brazil, as well as other social protest movements (such as the events associated to Ocuppy and Indignados). Emerging in the urban environment in the last decade, these events associated the problem of living in cities to a radical criticism of the political and economic world order. The goal is not to offer a definitive comprehension about the social protest movements but, on the contrary, reflecting critically about important concepts presented in Beck's theory, therefore discussing the extent to which these notions could contribute to the clarification of the political meaning of these events. Drawn up in the form of essay, the text argues, under various angles, by the advantages and limits of Beck's Sociology of risk, highlighting a counterpoint with those new critical theories committed with the purpose of thinking political subjectivity as event, like it occurs in Jacques Rancière and Slavoj Žižek.
\end{abstract}

Keywords: risk, democracy, social movements, new rights.

\section{REFERÊNCIAS BIBLIOGRÁFICAS}

ACOSTA, Virgínia García. El Riesgo como construcción social y la construcción social de riesgos. Desacatos. Septiembre-diciembre, n. 19. Centro de Investigaciones y Estudios en Antropologia Social. Distrito Federal, México, 2005.

AYALA-CARCEDO, Francisco Javier. Introducción al análisis y gestión de riesgos. In: AYALA-CARCEDO, Francisco Javier; CANTOS, Jorge Olciona (orgs.). Riesgos Naturales. Barcelona: Ariel, 2002, 1516 p.

BECK, Ülrich. World at risk Translated by Ciaran Cronin. Cambridge: Polity Press, 2009.

Sociedade de risco: rumo a uma outra modernidade. Tradução Sebastião Nascimento. São Paulo: Edições 34, 2010, $367 \mathrm{p}$.

Ecological politics in an age of risk. Translated by Amos Weisz. London: Polity Press, 1995. 215 p. Potere e Contrapotere nell'etá globale. Traduzione di Carlo Sandrelli. Roma: Laterza, 2010 [2002], 455 p. La revuelta de la desigualdad: El enriquecimiento rápido convirtió a muchos en dependientes de la droga del dinero prestado. Ahora los ricos poseen un poco menos, pero a los pobres no les alcanza para vivir. La

\footnotetext{
${ }^{102}$ No mesmo sentido, acerca do movimento Occupy, Žižek observou que as demandas imediatas dos manifestantes não deveriam ser compreendidas como "questões para as quais devem produzir respostas claras ou programas sobre o que fazer", e sim como respostas para as quais os intelectuais deveriam formular as questões pertinentes. ŽIŽEK, Slavoj. O ano em que sonhamos perigosamente. Tradução Rogério Bettoni. São Paulo: Boitempo, 2012. 140 p., p. 94-95. vol.08, nº. 03, Rio de Janeiro, 2015.pp. 1913-1948 
situación es (pre)revolucionaria. El País. Madri. 04 maio 2009. Disponível em: <http://elpais.com/diario/2009/05/04/opinion/1241388011_8502 15.html>.Acesso em: 15 mar. 2015

BROWN, Wendy. Oggi Siamo tutti democratici... In: AGAMBEM, Giorgio [et. al.]. In che stato é la democrazia? Traduzioni di Andrea Aureli e Carlo Milani. Roma: Nottetempo, 2010 [2009], p. 71-95.

CAUBET, Christian. O conceito de sociedade de risco como autoabsolvição das sociedades industriais infensas à responsabilidade jurídica. Cadernos de Direito. Piracicaba, v. 13 (24): 63-84. Jan./jun. 2013. Disponível em: <https://www.metodista.br/revistas/revistas-unimep/index.php/direito/article/viewArticle/ 1204>. Acesso em 15.04.2015.

DIAS, Bruno Peixa; NEVES, José. Introdução. In: DIAS, Bruno Peixa; NEVES, José (coord.). A política dos muitos: povo, classes e multidão. Lisboa: Tinta da China, jun. 2010, 446 p.

DOUGLAS, Mary. Risk aceptability according to the social sciences. New York: Routledge, 2003 [1985].

FIGUEIREDO, Rubens. A "espiral do silêncio e a escalada da insatisfação". In: FIGUEIREDO, Rubens (org.) A sociedade enfrenta o Estado. São Paulo: Summus, 2014.

GOHN, Maria da Glória. Manifestações de junho de 2013 no Brasil e praças de indignados no mundo. Petrópolis: Vozes, 2014, 157 p.

GOLDBLATT, David. Teoria Social e Ambiente. Tradução Ana Maria André. Lisboa: Instituto Piaget, 1998.

GUIVANT, Julia S. A trajetória das análises de risco: da periferia ao centro da teoria social. Disponível em: $<$ http://www.iris.ufsc.br/pdf/trajetoriasdasanalises derisco.pdf>. Acesso em: 17 de março de 2011. Também publicado na Revista Brasileira de Informações Bibliográficas - ANPOCS. No 46, 1998, p. 3-38.

HARVEY, David. O novo imperialismo. Tradução Adail Sobral, Maria Stela Gonçalves. 7 ed. São Paulo: Loyola, 2013, 201 p., p. 115-148.

Cidades Rebeldes: do direito à cidade à revolução urbana. São Paulo: Martins Fontes, 2014,294p.

A liberdade da cidade. In: MARICATO, Ermínia. [et al.] Cidades rebeldes: Passe Livre e as manifestações que tomaram as ruas do Brasil. 1 ed. São Paulo: Boitempo: Carta Maior, 2013. p. 25-34.

JASANOFF, Sheila. Direito. In: JAMIESON, Dale (coord.). Manual de Filosofia do Ambiente. Tradução de João C. Duarte. Lisboa: Instituto Piaget, 2005 [2003].

KEUCHEYAN, Ramzig. The Left Hemisohere: mapping critical theory today. Translated by Gregory Elliott. London: Verso, 2013, 264 p.

MARANDOLA JR., Eduardo; HOGAN, Daniel Joseph. O risco em perspectiva: tendências e abordagens. In: GEOSUL: Revista do Departamento de Geociências da Universidade Federal de Santa Catarina. Centro de Filosofia e Ciências Humanas. v. 19, n. 38, jul./dez 2004. Semestral. ISSN 0103-3964. Florianópolis: Editora da UFSC, 2004. 246 p.,p. 25-58.

MASKREY, Andrew. El Riesgo. In: MASKREY, Andrew (org.). Navegando entre brumas. La aplicación de los sistemas de información geográfica al análisis de riesgos en América Latina. Bogotá: Intermediate Technology 
Development Group (ITDG)/Red de Estudios Sociales en Prevención de Desastres en América Latina - RED, 1998, p. 20-26.

MOVIMENTO PASSE LIVRE. Não começou em Salvador, não vai terminar em São Paulo. Maricato, Ermínia [et. al.] Cidades Rebeldes: passe livre e as manifestações que tomaram as ruas do Brasil. São Paulo: Boitempo, 2013. 112 p.p. 13-18

RANCIÈRE, Jacques. O desentendimento: política e filosofia. tradução de Ângela Leite Lopes. São Paulo: 34, 1996, $144 \mathrm{p}$.

A partilha do sensível: estética e política. tradução de Mônica Costa Netto. São Paulo: 34, 2005.72 p.

Staging the people: the proletarian and his double. Translated By David Fernback. London Verso, 2011.

2012

The intellectual and his people: staging the people vol. 2. Translated By David Fernback. London Verso,

O mestre ignorante: cinco lições sobre a emancipação intelectual. Tradução Lillian do Valle. Autêntica: Belo Horizonte, 2002, 143 p.

O espectador emancipado. Tradução Ivon Benedetti. São Paulo: Martins Fontes, 2012, p. 128 p.

O ódio à democracia. Tradução Marina Echalar. São Paulo: Boitempo, 2014, 125 p.

A comunidade como dissentimento: Jacques Rancière (com François Noudelman). In: DIAS, Bruno Peixa; NEVES, José (coord.). A política dos muitos: povo, classes e multidão. Lisboa: Tinta da China, jun. 2010. p. 425-436.

ROGERS, Simon. Occupy protests around the world: full list visualised. The Guardian. London, p. 1-2. 14 nov. 2011. Disponível em: <http://www.theguardian.com/news /datablog/interactive/2011/oct/18/occupyprotests-map-world >. Acesso em: 08 mar. 2015.

SILVEIRA, Clóvis Eduardo Malinverni. Risco Ecológico Abusivo: a tutela do patrimônio ambiental nos Processos Coletivos em face do risco socialmente intolerável: Caxias do Sul: EDUCS, 2014, 398 p.

Uma breve análise sobre a integração entre as dimensões científica e axiológica na construção do risco ambiental. Revista Eletrônica Direito e Política, Programa de Pós-Graduação Stricto Sensu em Ciência Jurídica da UNIVALI, Itajaí, v.8, n.1, 1º quadrimestre de 2013. Disponível em: www.univali.br/direitoepolitica - ISSN 19807791

VEYRET, Yvette (org.). Os riscos: o homem com agressor e vítima do meio ambiente. Tradução Dilson Ferreira da Cruz. 1 ed. São Paulo: Contexto, 2007.

ŽIŽEK, Slavoj. Elogio da intolerância. Tradução Miguel Serras Pereira. Lisboa: Relógio D'Água, 2006, 148 p. O ano em que sonhamos perigosamente. Tradução Rogério Bettoni. São Paulo: Boitempo, 2012. 140 p.

O Sujeito incômodo: o centro ausente da ontologia política. Tradução Carlos Correia Monteiro de Oliveira. Lisboa: Relógio D'Água, 2009.400 p.

Trabalho enviado em 20 de agosto de 2015.

Aceito em 22 de outubro de 2015. 